
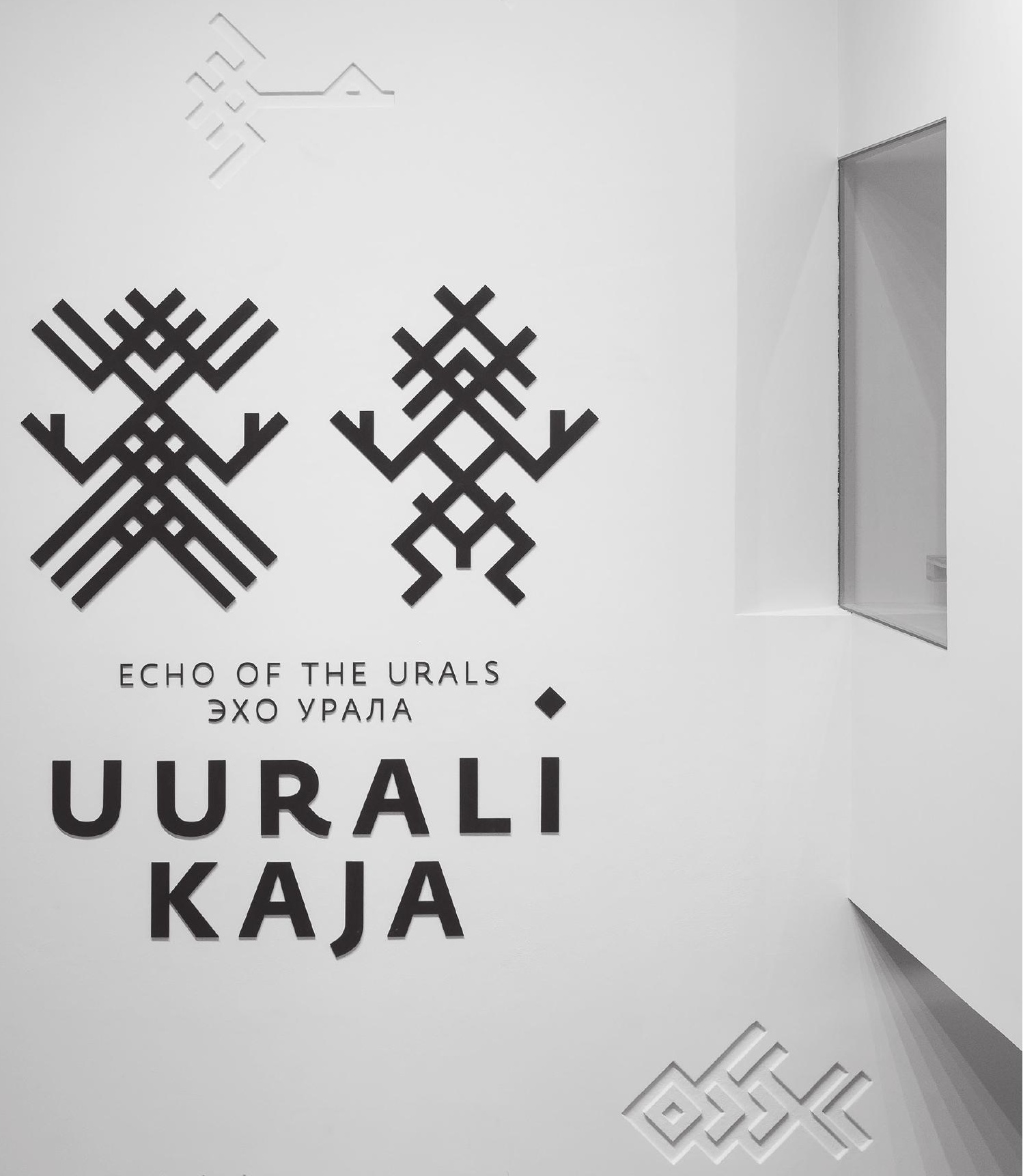


\title{
Uurali kaja Eesti Rahva Muuseumis ${ }^{1}$
}

\author{
Svetlana Karm
}

Art Leete

Hõimrahwaste osakond E. R. Muuseumis on wäikene: me ei saa teda võrrelda näit Soome Rahwamuuseumi Soome-Ugri osakonnaga, ei kogude suuruselt ega ruumi ulatuselt kuid mingisuguse pildi waataja hõimrahwaste kultuurist siiski saab. I---/ Osakonna ruumilise laiendamise peale ei saa aga nii kaua mõeldagi, kuni muuseum asub Raadi mõisas - peaks aga aastakümnete pärast awanema wõimalus muuseumile wäärilist maja ehitada, siis on kahtlemata ka hõimrahwaste kogud see wõrra kaswanud, et nad seal wäärilise esinduse leiawad.

Selliste sõnadega lõpetas 1928. aasta detsembri viimastel päevadel Raadi mõisahoones avatud hõimurahvaste osakonda tutvustava artikli tulevane TÜ etnoloogiaprofessor Gustav Ränk (Postimees, 8. jaanuar 1929). Tol ajal Raadi mõisahoones asunud muuseum kasutas soomeugrilaste kultuuri esitlemiseks kahte ruumi ning välja oli pandud $545^{2}$ eset - see oligi kogu tollane ERMi soome-ugri esemekogu. Kuni 1936. aastani publikule avatud hõimurahvaste vaatekogu võib pidada ERMi esimeseks soome-ugri püsiekspositsiooniks. Edaspidi on ajutise iseloomuga soome-ugri näitusi muuseumis pidevalt korraldatud. (ERMi soome-ugri näitustest vt Karm, Leete $2014 ;$ 2015.)

2016. aastaks ringiga tagasi Raadile jõudnud ERMi uues hoones on koos eesti püsinäitusega „Kohtumised“ (näitusest lähemalt vt Rattus 2014; 2016) üleval ka soome-ugri kultuuride püsinäitus „Uurali kaja“, mille meeskond on järgmine: kuraatorid Art Leete (TÜ, kontseptsioon), Svetlana Karm (juhtkuraator), Piret Koo-

[1] Artikli valmimist on toetanud Eesti Teadusagentuur (projekt PUT590) ja Hõimurahvaste programm (projekt nr 782).

[2] Selline number on ERMi 1928./1929. a aruandes (ERM A), tolleaegsed soome-ugri näitust kajastavad ajaleheartiklid nimetavad erinevaid numbreid: u 300 ja u 520 eset. (E. R. Muuseumi hõimurahvaste osakond avati. - Päevaleht, 29.12.1928: 6; Raadi muuseum suureneb. Postimees, 28.12.1928: 5; Hõimrahwaste osakond E. R. Muuseumis. - Postimees, 8.01.1929: 7) 
sa, Indrek Jääts (ERM), Madis Arukask, Nikolai Kuznetsov (TÜ); arhitektuur: Jan Graps, Anne Määrmann, Ken Kristjan Ruut (Janken Wisespace); disain ja multimeedia: Kristian Kirsfeldt, Kaarel Vahtramäe, Martin Kenkmaa, Siim Tikk, Magnus Haravee, Kadri Pukk, Keijo Kraus, Pärtel Vurma, Reimo Unt, Madis Lunkov, Rainer Kull, Kaimo Kure, Reijo Lell (Velvet); produtsendid: Viljar Pohhomov (ERM), Mart Lankots (Velvet).

Uuel näitusel on väljas 19 soome-ugri ja samojeedi rahva etnograafilisi esemeid, multimeedia abil on esindatud 25 rahvast, saab näha u 300 fotot, kümmekond joonist ning filmi- ja videomaterjali. „Uurali kaja“ näol on tegemist ainulaadse väljapanekuga, sest teist soome-ugri kultuuridele pühendatud püsinäitust, kus oleksid korraga esindatud kõik uurali rahvad, tänapäeva maailma muuseumiruumis lihtsalt ei ole. ${ }^{3}$

Käesolev artikkel heidab analüütilise pilgu ERMi soome-ugri püsinäituse „Uurali kaja" tegemise köögipoolele ning annab ülevaate näitusega seotud arutlustest, metoodilistest ja ideoloogilistest lähtepunktidest ning ettevalmistamise käigus tehtud valikutest. Oleme näituse ajaloolist tausta, kontseptuaalseid lähtekohti ja ettevalmistuse käiku analüüsinud varemgi (Karm, Leete 2014; 2015; Leete, Karm 2015). Nüüd, pärast „Uurali kaja“ väljapaneku avamist on võimalik näituse tegemisele tagasi vaadata ning lootuste täitumist või luhtumist paremini hinnata. Näituse detailide kohendamine, vigade parandamine ja täiendavad tööd on jätkunud ka pärast ERMi uue maja avamist. Ent sellegipoolest on aeg küps reflekteerimiseks. Kõik ajad on retrospektiivseteks analüüsideks sobivad, ent iga hetk on selleks ka eriline. Näituse avamisest möödunud aja vähesus on selles mõttes nii puudus (sest mõtlemisaeg on olnud põgus) kui ka unikaalsust loov tunnetuslik tõik (praegusest vahetumat teaduslikku peegeldust selle näituse tegemisest enam luua ei saa).

„Uurali kaja“ näitust on praeguseks palju arvustatud ja analüüsitud nii sotsiaalmeedias (vt nt Laanisto 2016; Petolai 2016; Salve 2016) kui ka ajakirjanduses (vt nt Mägi 2016; Seljamaa 2017; Sepp 2017; Silla 2017; Zõbin 2017) ja mujal (Lehtinen 2017). Ildiko Lehtinen peab näituse üldmuljet romantiseerituks, isegi ülistavaks (2017: 65, 67), ent tunnustab ka väljapaneku „haaret ja lummavust“ (samas: 67). Näituse põhilisteks probleemseteks kohtadeks on Lehtineni arvates kultuuri teisenemise ja üleilmastumise jälgede puudumine ning tänapäeva põletavate probleemide eiramine, aga ka identiteeditunnuste lihtsustamine stereotüüpide kujundamise eesmärgil (samas: 67-68). Marilyn Mägi (2016) märgib, et näitusel tekib kiiresti meelte üleküllastatuse tunne ning hõimurahvastest ei jää meelde midagi. Eva Liisa Sepp (2017) kritiseerib näitusel esitatud animafilmide ja nende aluseks valitud rahvajuttude seksistlikku hoiakut, ühtlasi ka seda, et filmitegijate seas oli vähe naisterahvaid. Teised analüüsijad on valdavalt positiivsed, ent huvitavad on just juhud, kui vaatajad on

[3] Soome-ugri kultuurid on esindatud näiteks ka Venemaa Etnograafiamuuseumi püsinäitusel, moodustades osa „Venemaa rahvaste paraadist" (lähemalt ekspositsioonist vt Baranov 2004). Venemaa soome-ugri kesk- ja rahvusmuuseumites on aga pearõhk oma regiooni rahvuste kultuuri ja ajaloo ning kohaliku identiteedi esitlemisel. Kõige pikema soome-ugri püsinäituste traditsiooniga on olnud Soome Rahvusmuuseum, kus esimene soome-ugri kultuuride püsinäitus avati juba 1923. a. Alates 2013. a aga muuseumi rikkalikud soome-ugri kogud näitustel esindatud ei ole (v.a virtuaalsed näitused). (Lehtinen 2017: 65-66) 


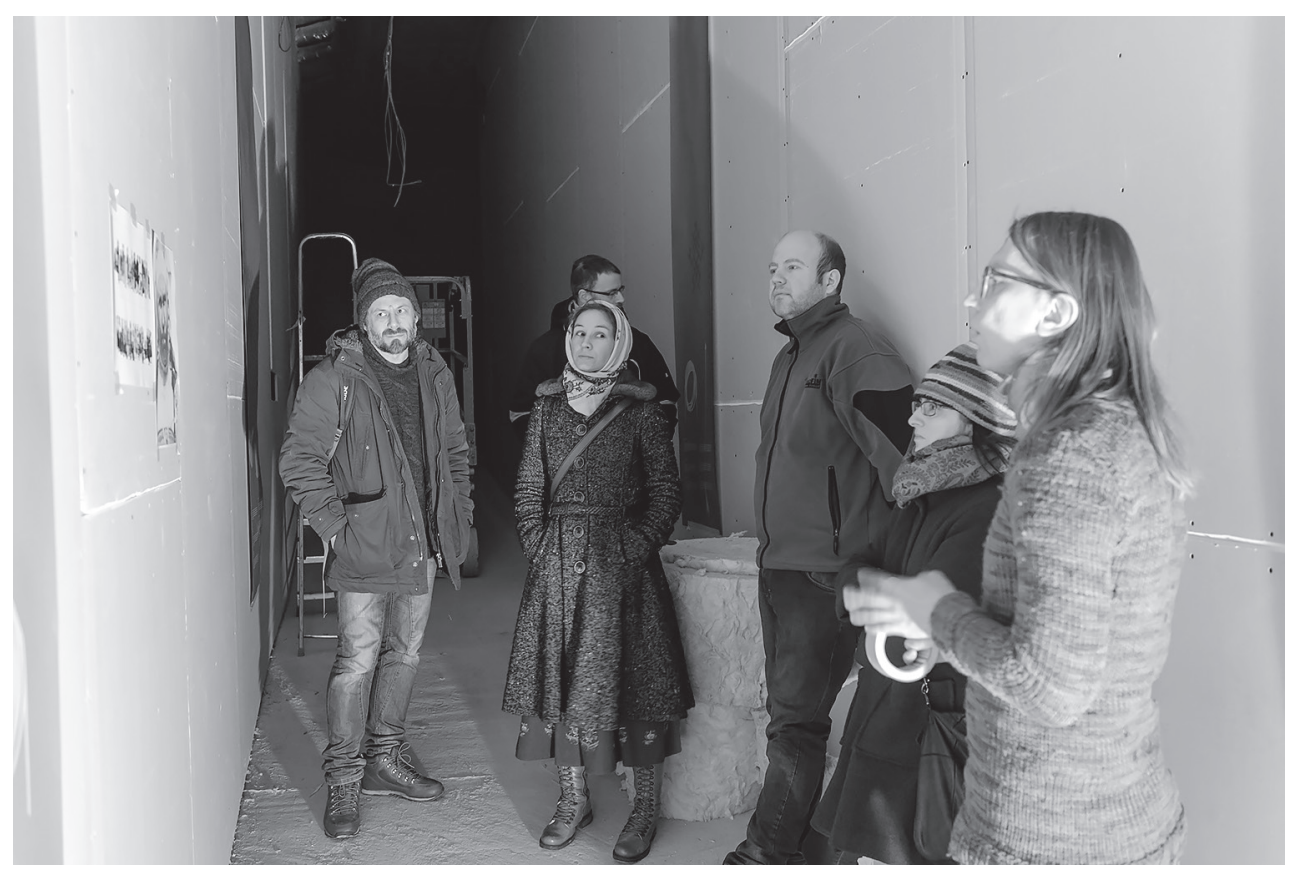

Üks paljudest näitusemeeskonna töökoosolekutest, seekord ehitusaegses näitusesaalis (praegu asuvad siin tunnelis vitriinid meeste-naiste paarisesemetega). Pildil on kuraatorid Art Leete, Piret Koosa, Indrek Jääts ja Svetlana Karm ning disainerid Mart Lankots ja Kristian Kirsfeldt.

Foto: Arp Karm, 7.01.2016

meid hukka mõistnud või pole lihtsalt mõistnud. Oleme oma käsitlust koostades natuke silmas pidanud ka vajadust diskuteerida meie näitusele suunatud kriitikaga.

Teoreetilises plaanis lähtume arusaamast, et püsinäitusi mõtestatakse tänapäeval sarnaselt ajutistele näitustele (Kotilainen 2007; Sandahl 2007; Viatte 2007). Toetume käsitlustele, mis mõtestavad muuseuminäitusi (sh püsinäitusi) eksperimentaalses võtmes (Basu 2007; Basu, Macdonald 2007; Porto 2007). Samuti lähtume lähenemistest, mille kohaselt püsinäitused pole tegelikkuse otsesed peegeldused, vaid tähenduste mängul põhinevad kultuuri tõlgendused (Bogaart 1983; Clifford 1988; Kirschenblatt-Gimblett 1991; Mathisen 2004). Üldiselt kasutame ka ideed, et esemed (mis on meie näituse tunnetuslikuks keskmeks) on suhtelised ning „subjekti/objekti erinevused luuakse eristamisprotsessis“ (Harvey, Knox 2014: 1). Seega ei omista me näituse kontekstis etnograafilisele esemele tähendust iseenesest, vaid suhestame selle korraga nii kultuuriga, millega ese on esialgselt seotud olnud, kuraatorite tõlgendusega kui ka muuseumikülastajate potentsiaalsete vastuvõtuviisidega. Esemed on tunnetuse, teadusliku reflektsiooni lähtepunktiks (samas).

Ehitasime oma uurimuse üles sarnaselt väljapaneku idee arengule. Esmalt lahkame esimesi põhimõttelisi ning üldisi arutelusid ja mõtteid, millest praeguse püsinäituse koostamine alguse sai. Seejärel käsitleme ekspositsiooni kontseptuaalse tuuma kujunemist ning kogude seostamist näituse ideega. Kolmandaks arutame näituse kontseptsiooni üle, lõpuks aga analüüsime kaasatõmbavaid lahendusi, mida 
näitusel kasutati (keskendudes mängulisuse ja teadusliku sisu tasakaalule). Just kaasahaaravates stseenides ja objektides näeme „Uurali kaja“ näituse populaarsuse ja edu võtit (meile tundub, et taoline külastajate kõnetamise viis osutus adekvaatseks) ning viisi muuseumiesemete tähenduste esiletoomiseks, sest interaktiivsete objektide ja installatsioonide ettevalmistamine koondas kujundustoimkondade koostööd ning suunas meid üksteise lähenemisviisidesse eriliselt süvenema. Seega ühendavad interaktsioonid näituse valmimise protsessi nii tegevuste kui ka mõistmise vallas.

\section{Soome-ugri püsinäituse kontseptsiooni museoloogiline taust}

Põhimõtteliselt on ammu teada, et muuseumid on võimsad vahendid identiteetide konstrueerimiseks (Karp 1991: 15-16). Muuseumide tegeliku mõju potentsiaal sõltub aga paljuski sellest, kui atraktiivsed nad suudavad olla. See haaravuse ja sõnumi tuumakuse tasakaal on õrn ning selle saavutamine keeruline, sest tõsiseltvõetavust ja lõbu pole lihtne omavahel põimida.

Muuseumid tegutsevad kultuuride ja vaatenurkade ristteel. Kultuuridevahelised näitused esitavad väljakutseid ja muudavad kogemuse kaudu nii etnograafide kui ka külastajate teadmisi. See ei juhtu aga iseenesest. Näitusekülastajatele tuleb näitusega pakkuda võimalus oma teadmiste ja tunnete ümberkorraldamiseks (Karp 1991: 22-23). Muuseumide näitusestrateegiad on tavaliselt koostatud nii, et need kajastaksid tegeliku elu kultuurilist komplekssust ja vastuolulisust. Samas on klassikaline idee, mille kohaselt muuseumikogud esindavad kultuuri adekvaatselt, illusioon (vt Clifford 1988: 227-228; Kirschenblatt-Gimblett 1991). Sellegipoolest kajastavad konstrueeritud kultuurifragmendid mingit laadi autentsust. Muuseum katkestab küll kultuuri esialgsuse, ent see säilib siiski üksikute objektide kaudu, peegeldades mõnevõrra tervikut, millest need esemed pärinevad. Teisalt eksisteerib kuraatorite jaoks poolvaistlik kood, mille abil taasluuakse muuseumikogude põhjal kultuurilisi üldistusi, millel on komplitseeritud autentsusseos muuseumivälise eluga.

Muuseumid ja nende kogud ei peegelda mitte niivõrd uuritavate tegelikku elu, vaid muuseumitöötajate arusaamist sellest. Dokumenteeritakse neid omadusi ja nähtusi, mis mõjutavad teadlasi ja kuraatoreid ja mida nad oluliseks peavad. Seega räägivad muuseumikogud ja näitused rohkem meist endist kui teistest. (Bogaart 1983: 13)

Taoliste arutluste valguses on kohane tõdeda, et uusi näitusi tehakse alati varasemate väljapanekute taustal. Muuseumikollektsioonid aktualiseerivad mälestusi endistest näitustest, mis on mõjutanud muuseumi üldist näituste ettevalmistamise protsessi. Lisaks asetub näitus ka muuseumi varasema selleteemalise kogumis- ja uurimistöö konteksti, seda muidugi juhul, kui kuraatoriteks on muuseumiga seotud teadlased, mitte spetsiaalselt uusi, senisest muuseumi näitusepraktikast sõltumatuid tõlgendusi looma kutsutud kunstnikud.

Soome-ugri temaatikaga on ERM tegelenud algaastatest saati. See oli aktuaalne juba 20. sajandi alguses, mil hakati ehitama rahvusriiki ning pandi alus ERMi hõi- 
murahvaste kogule (Tallgren 1921; 1923; Manninen 1924: 527-528, 530-532; Ernits 1926: 89-90). Soome-ugri uurimistöö oli oluline ka nõukogude ajal, mil soomeugrilaste kultuuripärandiga tegelemine aitas edendada koostööd teiste Nõukogude Liidu ja naaberriikide teadusasutustega ning võimaldas pääseda sotsialistliku kaasaja uurimisest, millel „lasus poliitilise tellimuslikkuse vari“ (Konksi 2009: 288; Karm 2011: 102-103). Praegugi on soome-ugri teema ERMile tähtis, sest nüüdsel ajal püütakse säilitada Euroopas „oma nägu“ (Kirch 2002: 91; Heinapuu 2007: 1). Aastate jooksul on muuseumi arhiividesse ja kogudesse laekunud ligi 200 hõimurahvaste aladel toimunud ekspeditsiooni materjalid - esemed, fotod, etnograafilised joonised, käsikirjad ning filmi- ja videodokumendid (Auasi 2008: 49-55).

Ilmselt ei oleks ERMi uue hoone sisustamisel soome-ugri näituse teema päevakordagi tulnud, kui muuseumil ei oleks näidata rikkalikke soome-ugri kultuuride kogusid. Samas ainult kogude olemasolust ei piisa püsinäituse korraldamiseks. Tänapäeva muuseumimaastikul on aina rohkem uusi ja pika ajalooga uuenenud muuseume, mis loobuvad püsinäitustest ülevaatlike väljapanekute või lühiajaliste kontseptuaalsete näituseprojektide kasuks (Foorum 2007). Isegi kui püsinäitusest pole loobutud, on nende väljapanekute iseloom muutunud paindlikumaks ning klassikaline erinevus näitusežanrite vahel hakkab kaduma. Ähmane erinevus püsija ajutiste näituste vahel on pannud muuseumide kuraatoreid tänapäeval tunnistama asjaolu, et püsinäitusi tuleb mõtestada samamoodi nagu ajutisi väljapanekuid (Kotilainen 2007: 54). Selline strateegia muudab lühi- ja pikaajalised näitused üksteisele kontseptuaalses plaanis sarnaseks. Kujunev vastuoluline piir nende kahe klassikalise muuseumiväljapaneku mudeli vahel kujundab uudse dialoogi kuraatorite ja külastajate vahel ning suunab muuseume eksperimentaalsemate näituste loomise suunas. Näitena võib tuua kasvõi 2004. aastal Göteborgis avatud maailma kultuuride muuseumi (Världskulturmuseerna), kus traditsioonilise püsinäituse asemel on ajutiste näituste galerii, mis võimaldab korraldada erinevaid väljapanekuid ja tuua näitusesaali sotsiaalselt olulisi teemasid (Sandahl 2007: 91-92). Pariisis 2006. aastal avatud Quai Branly muuseumi püsiekspositsioon aga kujutab endast suurt valikut hoone arhitektuuriga kooskõlas olevaid mitteeuroopa rahvaste eksponaate - skulptuure, tekstiili, rituaalideks kasutatavaid objekte, muusikariistu jmt, mis peavad esile tooma uue muuseumi kontseptsiooni kunstide muuseumina. Siin on pearõhk vahetatavatel näitustel ja erinevate ekspositsioonidega seotud teatri-, tantsu-, muusikaetendustel, mis aitavad kujundada muuseumist kultuuride, tsivilisatsioonide ja inimeste kohtumispaiga (Viatte 2007: 29-30; Fofin 2011: 161).

ERMi soome-ugri näituse ideeline ettevalmistamine algas juba 2000. aastate alguses, kui hakati otsima kohta uue muuseumihoone jaoks ja valmistati ette rahvusvahelist konkurssi muuseumihoone parima projekti leidmiseks (konkurss kuulutati välja 2005. aastal ning selle tulemused avalikustati 2006. aasta jaanuaris). Uue hoone projekti kirjutati sisse ka soome-ugri näituse ruumid, kuid esialgu ei olnud muuseumil kindlat nägemust, milline see tuleb - kas püsinäitus või ülevaatlik väljapanek koos vahetatavate ajutiste temaatiliste näitustega.

Püsiekspositsiooni kavandamise käigus kerkivad küsimused püsivusest ja muutuste potentsiaalist näitusel. Michael Belcher (1991: 45-47) väidab, et püsinäitustele on omane tendents rakendada konservatiivseid esitlusviise, mis võimaldavad vali- 

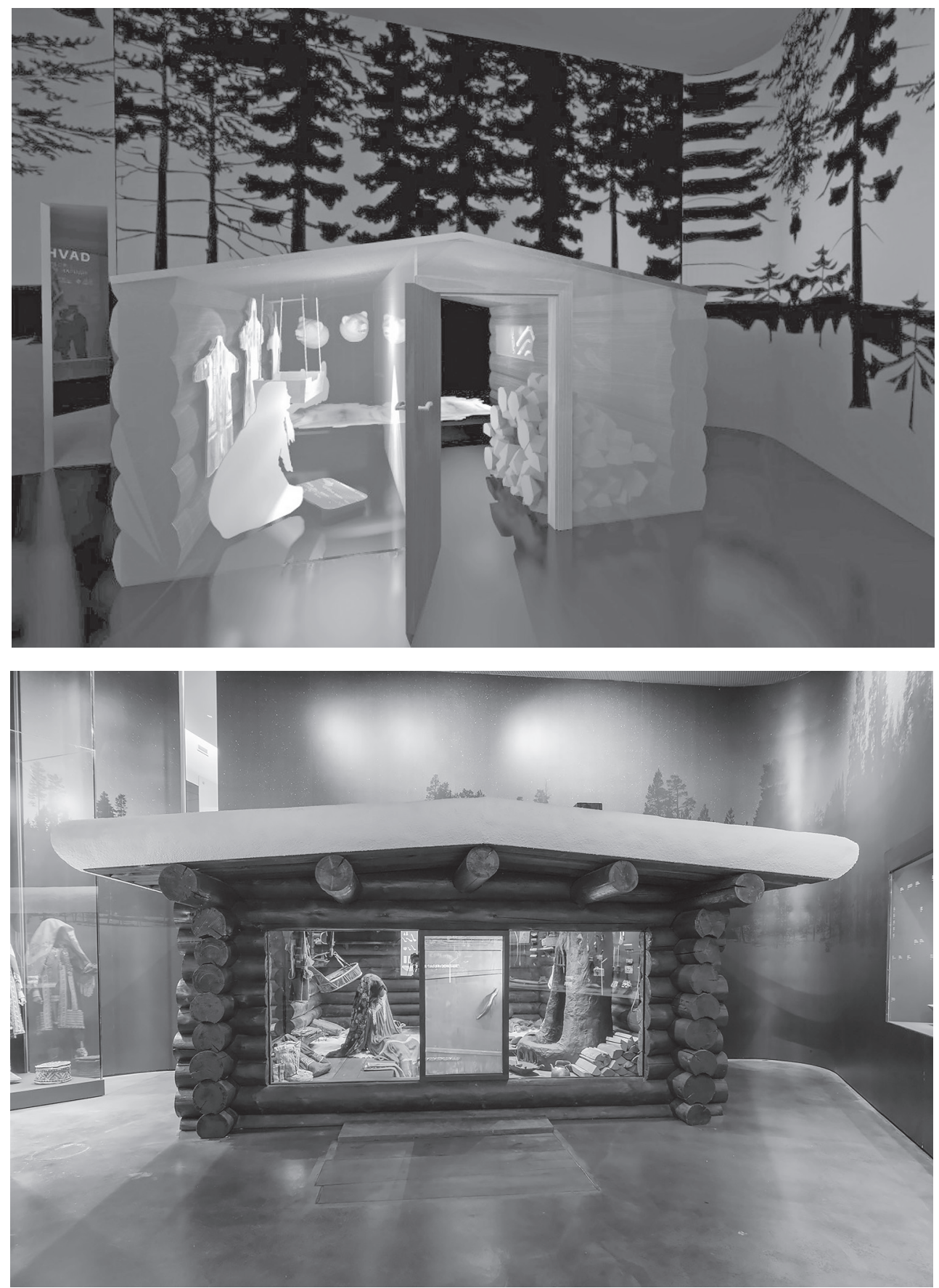

Põhjarahvaste saal. Vaade handi tarele arhitektide tööjoonisel (detsember 2011) ja vast avatud näitusel (oktoober 2016). 
tud objekte pika aja vältel eksponeerida (vt ka Runnel 2015: 109-110). Taolised näitused on tavaliselt kultuuriajaloo ülevaateväljapanekud, mis eeldavad mahukaid investeeringuid ja ressursse. Seetõttu on püsinäitustega seoses kasutatud kollektiivse monograafia metafoori, samal ajal kui ajutisi näitusi võrreldakse teaduslike artiklite või kontseptuaalsete esseedega (Baranov 2017: 71-72; Tšistov 2007: 111-112; Zassetskaja 2013: 109). Ent taolisest „monograafilisest“ lähenemisest külastajatele jääv objektiivsuse mulje on petlik. Kui aga kuraatorid loobuvad autentse etnograafilise reaalsuse taasloomise püüdest, tuleb leida muid viise ebaloomulikkuse mulje ärahoidmiseks (Baranov 2007: 24). Ajutised näitused on tavaliselt uuenduslikumad ja sõltuvad vähem muuseumide kollektsioonide sisust (Arsenjev 2007: 11). Kui ajutisi näitusi on kergem tunnetada vaba ideede voo tulemusena, siis püsinäitustelt eeldatakse ikkagi tõsisema argumendi esitlust.

Kavandades uude majja soome-ugri ekspositsiooni, otsis muuseum samal ajal vastuseid küsimustele, kuidas seostub soome-ugri temaatika rahvusmuuseumi kui sotsiaalsete ja kultuuriliste identiteetide kujundaja ning maa ja rahvuse mälukandja rolliga ${ }^{4}$ ning kas ja kuivõrd on aktuaalne tänapäeva globaliseeruvas maailmas etnilise päritolu rõhutamine. Nimelt väljendati avalikel aruteludel kahtlusi etniliselt orienteeritud soome-ugri näituse sobivuse üle Euroopa muuseumimaastikule, samal ajal pakuti aga välja näituse etnograafiline aspekt (Runnel et al. 2010: 328-329).

Soome-ugri püsinäituse kasuks rääkisid 2006. aasta oktoobris toimunud ümarlaua „Kas ja millist hõimurahvaste püsinäitust vajab Eesti Rahva Muuseum uues peahoones Raadil?“" osalejad - etnoloogid, keeleteadlased, kirjanikud, kunstnikud, muuseumitöötajad, tudengid, kultuuritegelased jt. Veelgi enam, koos viitamisega muuseumi (selle näol ka kogu eesti rahva) erilisele rollile olla "suguvendadele küünarnukitunde ja võimaluse pakkujaks „oma asjade“ ajamiseks” ning selliste küsimustega nagu „Kes peaks soome-ugri asju uurima kui mitte soomeugrilased ise?" jäi kindlalt kõlama osalejate seisukoht, et soome-ugri teema on kontseptuaalselt seotud eesti kultuuriga ning toetab eesti identiteeti (Karm 2011: 102). Seega oli selge, et ERMi uude hoonesse peab koos eesti kultuuri käsitleva püsinäitusega tulema ka soome-ugri püsinäitus, sest soome-ugri keelesuguluse ideega kokku köidetud rahvaste iseolemine toimib ka 21. sajandi algul eestlastele jätkuvalt „omamoodi peeglina, kuhu vaatamine on kinnitanud usku omaenda eksistentsi ja toitnud rahvuslikku müüdiloomet" (Seljamaa 2017: 55).

Omariikluseta uurali rahvastele pühendumisega on ERM võtnud endale eestkõneleja (Seljamaa 2017), hõimurahvaste tugipunkti ja soome-ugri kultuuride Euroopa saatkonna rolli (Arengukava). Siiski, kui väga tunnetuslikult lähedane soomeugri temaatika eestlastele ka poleks, on „Uurali kaja“ näol tegemist näitusega, kus eksponeeritakse ikkagi teisi, eestlastest erinevaid rahvaid ja kultuure. Samas haakub näitus rahvusvaheliste väikerahvaid puudutavate diskussioonide ja lähenemistega ning arendab välja uue soome-ugri diskursuse, mis seob rahvusmuuseumi

[4] Tänapäeval seatakse kahtluse alla isegi rahvusmuuseumi idee ja selle olemasolu vajadus: „Unustage ära national, seda ei ole enam, meil on positiivne globaliseerumine!“ (Õunapuu 2006: 33, tsiteerib norralast Marc Maure'i). 
kontseptsiooni mitmekultuurilise lähenemisega ning toetab etniliste gruppide kultuuriliste väärtuste ja omapärade tutvustamist. ${ }^{5}$

Teise rahva representeerimisega käib kaasas rida erisusi, sest me lihtsalt ei taju loomulikul viisil, iseenesestmõistetavalt kultuuri, milles me ise pidevalt ei osale. Oleme küll kõik soomeugrilased, ent see seos on abstraktne, ning eksistentsiaalse kultuuritunnetuse mõttes pole sellest teoreetilisest asjaolust palju abi. Teise representeerimine muudab tahes-tahtmata suhte muuseumi ja esitletavate vahel hierarhiliseks, aga kasvatab ka näitusetegijate vastutust esitletavate rahvaste ees (Seljamaa 2017).

Küsimus pole ainult selles, et kuraatorid teevad näitust rahvastest, kelle kultuuritunnetus on neile rangelt võttes kättesaamatu. Sarnases seisus on ka näituse külastajad, kelle jaoks on võõraid kultuure kujutava näitusega suhestumine kardetavasti problemaatiline. Sellele murekohale on tähelepanu juhtinud Eija-Maija Kotilainen Soome Kultuuride Muuseumist:

Külastaja isiklikud mälestused võivad edukalt käivituda neil juhtudel, kui näitus esitleb kultuuripärandit, mida vaataja peab enda omaks. Ent kui muuseumikülastaja näeb endale võõra kultuuri näitust, on tal raskem kasutada mõistmisel oma isiklikku kogemust. Sel juhul ei saa näitus arvestada ainult külastajate isiklike empiiriliste teadmistega, vaid peab toetuma kaudsematele universaalsete kogemuste ja samastumise vormidele. Tänapäeval on pea kõik muuseumitöötajad nõus sellega, et parimad näitused ühendavad faktide esitluse ja kogemuse rakenduse. Isikliku kogemuse aktiveerimine soodustab teadmiste omandamist sügavamal tasandil, see avab intuitiivse taju ja võimaldab un vaadet erinevatele küsimustele. (Kotilainen 2007: 52)

Taoline kokkupuutepunktide otsimine näitab, et tänapäeva museoloogias nagu ka kultuuriuuringutes üldisemalt on tähtis roll dialoogil ja osalusel. On selge, et muuseum saab rääkida teistest kultuuridest, kuid mitte nende eest. Muuseum võib kõnetada külastajaid koos nendega, kelle kultuuripärandit ta talletab ja uurib. (Samas: 51-52)

Ehkki muuseumikogude autentsus sõltub inimeste poolt kuraatorite käsutusse antud informatsioonist ja arvamustest, on ainese mõtestamine pikalt olnud näitusetoimkondade kontrolli all. Seetõttu ei saa rahvas näituste koostamisel eriti kaasa rääkida ning sellisel juhul on keeruline kõneleda tegelikust „jagatud autorlusest“ (Runnel et al. 2010: 333). Tänapäeval peetakse põhimõtteliselt normaalseks publiku kaasamist muuseuminarratiivide kujundamisse (ibid.: 326; Tatsi 2011: 65). Kui aga kuraatorid tulevase publikuga dialoogi ei otsi, muutub näituse ettevalmistus äraarvamismänguks (Runnel et al. 2010: 335). Asjahuvilistest ja ekspertidest külastajate osalus on samas alati ebakindla olemuse ja tulemusega protsess. Sellegipoolest integreeritakse erinevaid osalusviise näituse ülesehitusse üha enam (Tatsi 2011: 76). Ka ERMi soome-ugri püsinäituse toimkond hoidis pidevat kontakti nii soome-ugri

[5] Näituse kuraatorite meeskond pälvis 2017. aastal Avatud Eesti Fondi Koosmeele auhinna. 1997. aastal loodud Koosmeele auhinnaga tänab Avatud Eesti Fond oma igakevadisel sünnipäeval neid inimesi ja organisatsioone, kes on oma tegevusega aidanud kaasa avatud ühiskonna kujunemisele nii Eestis kui mujal (täpsemalt auhinnast vt: https://oef.org.ee/ teoksil/koostoo-dialoog-debatt/koosmeel/). 
etnograafia asjatundjate kui ka entusiastidega. Kujutasime ette, et soomeugrilased on meie kõige olulisem publik, kuigi nende kaasamine püsinäituse tegemise protsessi oli fragmentaarne.

Osaluse katkendlikkust põhjustavad mitmed tunnetuslikud ja praktilised asjaolud. Darja Agapova osutab sellega seoses vajadusele, et eksperdid peavad süvendama oma kommunikatiivset kompetentsust ning arendama oskust töötada mitmekultuurilises loomingulises keskkonnas. Taoline väljakutse toob kaasa vajaduse toime tulla ettenägematute asjaoludega ning olla senisest rohkem paindlik. Samuti ei sobitu selline strateegia hästi hierarhilise otsustamismudeliga. (2015: 10-11)

Soome-ugri põliskultuuri ekspertidele pakkusime osalust eeskätt konsultantide, ekspertide tasandil. Tõsi küll, kuraatorite toimkonnas olid lisaks eestlastele komi ja udmurdi esindajad. Rohkem kui 20 erinevat kultuuri käsitleva püsinäituse kuraatoritena ei näinud me võimalust ega ka vajadust kaasata tööprotsessi suurt kultuurikandjatest auditooriumit. Pikaajaline ja töömahukas projekt, nagu püsinäituse ettevalmistamine, eeldab lisaks kultuuri tundmisele ka museoloogilise konteksti tundmist ehk teadmisi uurimistraditsioonidest ja kogudest, aga ka valmidust pidevalt tegeleda väljapanekuga seotud küsimustega ning võtta vastutust tähtsate otsuste tegemisel. ${ }^{6}$ Seega kaasati aktiivselt Eestis õppivaid soome-ugri tudengeid ja Venemaa kolleege ja museolooge näituse produktsiooniprotsessi alguses, kui arutleti kontseptsiooni üle, ning lõpupoole, kui oli vaja täpsustada üksikuid asjaolusid seoses konkreetsete eksponaatidega (rahvarõivastest koopiate tegemine, mannekeenide riietamine, ehituslike objektide ja üksikute museaalide iseärasused jmt). Taoliselt paika pandud osaluse määr ja vormid olid sellist näitust tehes sisuliselt ja praktiliselt kõige põhjendatumad.

Teavitamistöö ERMi uue hoone ehitusest ja püsinäituste ettevalmistamisest soome-ugri aladele korraldatud välitööde käigus, kuraatorite aktiivsed kontaktid soomeugrilastest sõprade ja kolleegidega ning soome-ugri päritoluga giidid aitasid ja aitavad luua uuest ERMist kuvandi kui soomeugrilaste kohtumispaigast. Siin on toimunud nii hõimupäevade üritused kui ka Soome-Ugri Kirjanike Assotsiatsiooni Kongress (august 2017). ERM on ka 2020. aastal toimuva maailma soome-ugri rahvaste maailmakongressi ${ }^{7}$ võõrustaja.

[6] Kui mitte arvestada avalikke arutelusid ja käesoleva artikli autorite omavahelisi nõupidamisi (ning mõningaid otsuseid, mis tuli autoritel teha enne näituse toimkonna kogunemist), siis võib näituse ettevalmistamise protsessi alguseks pidada 9. maid 2008, kui toimus esimene soome-ugri püsinäituse koosolek (osalesid ERMi teadurid Indrek Jääts, Svetlana Karm, Marleen Metslaid (tollal Nõmmela), koguhoidja Maris Rosenthal ning TÜ etnoloogia professor Art Leete ja tollased etnoloogiatudengid Jaanika Jaanits ja Piret Koosa). I. Jääts, S. Karm, A. Leete ja P. Koosa jätkasid kuraatoritena kuni näituse avamiseni. 2010. a liitus kuraatorite meeskonnaga folklorist Madis Arukask (TÜ) ning 2011. a keeleteadlane Nikolai Kuznetsov (TÜ). Soome-ugri püsinäitus avati publikule samal ajal ERMi uue hoonega 1. oktoobril 2016.

[7] Soome-ugri rahvaste maailmakongress on soome-ugri ja samojeedi rahvaste valitsustest ja parteidest sõltumatu esindusfoorum. Kongressi eesmärgiks on arendada ja kaitsta soomeugri rahvaste rahvusteadvust, kultuure ja keeli ning edendada soome-ugri rahvaste omavahelist koostööd (lähemalt kongressist vt https://fennougria.ee/esinduskogud/maailmakongressid/). 
Muuseumikuraatorid peavad mõistma, millistesse kogukondadesse nad kuuluvad ja keda oma tegevusega teenivad. Muuseumid muutuvad pidevalt ning sealsed töötajad peavad oma tegevuse põhjendused aeg-ajalt uuesti läbi mõtlema. Muuseumide eksistentsi kommunikatiivsed, välised põhjused muutuvad tänapäeval üha olulisemateks, näidates kultuuripärandiga tegelemise seost muuseumi päevakajaliste ülesannetega (Watson 2007: 1-2). Üheks muuseumide missiooniks selles vallas on mujal ignoreeritud või ebapiisavalt esitletud kogukondade esindamine (samas: 8). Just sellise ülesande seadsimegi endale, tundes soomeugrilaste ees kultuurilist aukohustust.

Kuigi olime teadlikud oma sotsiaalse vastutuse aktuaalsusest (sest muuseumide ja kogukondade suhe kaldub tavaliselt esimese domineerimise poole - vt Watson 2007: 9-16), ei olnud erinevate ühiskonnagruppide osaluse küsimused püsinäituse ettevalmistamisel põhifookuses. Otsustasime loobuda laiaulatuslikust kaasamisest seetõttu, et kogukonnad, keda tajusime oma peamiste tunnetuslike partneritena, on soome-ugri rahvad ning seega oli kaasamine raskendatud ilmsel põhjusel - soomeugrilased elavad laiali suurel alal Eestist väljaspool (vrd Watson 2007: 11). Kuraatorite toimkonnal tuli eeskätt lahendada pakilisemaid esmase tunnetuse küsimusi. Keegi meist polnud varem püsinäitust teinud. Seega keskendusime eeskätt oma kogude tundmise parandamisele ja museoloogiliste teoreetiliste lähenemisviiside arendamisele.

Traditsiooniline näitusestrateegia kätkeb endas arusaama muuseumieseme erilisest rollist. Barbara Kirshenblatt-Gimblett (1991: 388) mõtestab eset etnograafilise fragmendina, mis esindab ja kehastab „,irdumise poeetikat", mis teeb võimalikuks selle imetlemise. Ese-fragment imiteerib ning potentsiaalselt ka taasloob puuduvat tervikut ja intensiivistab tegelikkuse nimbust. Kogudekesksed näitused luuakse ajalooetappide, rituaalide ja keskkondade eraldatud ja kokkukuhjatud mimeetilise peegeldusena (samas: 388-389). Klassikalises museoloogilises strateegias eeldab mimeetiline lähenemine autentsest keskkonnast eraldatud esemete lihtsat väljapanekut. Seega kujunesid taolised näitusekeskkonnad muutumatute, külmutatud otstarbega tarbeesemete panipaikadeks (Crew, Sims 1991: 159).

Esemed võimaldavad inimestel üksteisega suhestuda (Harvey, Knox 2014: 2), nad on sotsiaalselt läbipõimunud (samas: 10) ning muuseuminäitus annab nende suhete kaardistamiseks ja esiletulekuks ühe kultuurispetsiifilise võimaluse. Inimeste igapäevane esemeline kogemus „, on korrastatud klišeede, rutiinsete tajumustrite ja tegevuste poolt, mille raames esemed on korraga piiratud ja piiravad“ (Thoburn 2014: 208). Näituse üldine tunnetuslik siht on selle harjumuspära lõhkumine, tavapärase kaemuse nihestamine. Samas peab väljapanek kätkema ka tuttavlikkust, et külastajatel tekiks kokkupuutepunktid oma varasema tunnetusliku kogemusega. Samuti määrab antud juhul asjade arengut ka kogude seisukord.

Tegelikkust kloonida püüdvat väljapanekut saab teha elavamaks, kasutades lõimimise strateegiat. Tegelikkuse koopiad muutuvad tähendusrikkaks, kui kuraatorid kontekstualiseerivad etnograafilised esemed ning stseenid tugeva ja adekvaatse tunnetusliku kontrolli kaudu. Muuseuminäituse nautimiseks vajavad külastajad juhiseid. Inimestel on tarvis tausta või raamistikku, et kujundada esmapilgul gro- 
tesksed, robustsed, veidrad ning lihtsad esemed harivaks aineseks. Sel moel tagavad kuraatorid, et kultuuri kopeeritud katked pääsevad triviaalsusest (Kirshenblatt-Gimblett 1991: 390-393). Külastajatele peab olema selge, et kultuuri rekonstrueeritud killud esindavad midagi sügavalt tähendusrikast ning on ammendavalt põhjendatud teaduslike väidetega. Selline lähenemisviis ei välista meelelahutust, ent sõelub välja respektaablid muljed. Samuti tagatakse sel moel tunne, et iga esmapilgul juhusliku eseme taustal kumab teaduslik teooria.

Paljudes muuseumides on kuraatorid veendunud objektiivsuses ning eksponeerivad esemeid sellise metodoloogilise lähenemisviisi raames. Külastajadki ei taju esemeid metafooridena, vaid tegelikkuse otsese peegeldusena (Baranov 2007: 23-24). Vältimaks otsese esitluse illusiooni, peavad kuraatorid rakendama teistsuguseid lähenemisviise, teostades kultuuri eksplitsiitset esitlust mingil omapärasel viisil.

Nuno Porto (2007: 176) pakub välja „etnograafilise installatsiooni“ käsitluse, tähistamaks „eksperimentaalset etnograafilist loomet ja näitusetegemise protsesse". Selline induktiivne lähenemisviis eeldab spetsiifilise stsenaariumi ja stsenograafia kontekstualiseerimist, seostades need kordumatul moel valitud teema ja muuseumi ruumiga (samas: 175-177).

Taoline mõtteliin suunab meid eksperimenteerimise probleemi juurde püsinäitustel. Tänapäevased näitused väljendavad eksperimentaalset tähendusloomet ning on teadmiste kujundamise paigad (Basu, Macdonald 2007: 2-3). Narratiivid mõjuvad "mõtestavate radadena" näituse maastikul, tuues esile järjestikuseid kogemusi (Basu 2007: 53). Selline muuseum on „narratiivse potentsiaali ruum“, mis loob labürinditaolise "teekondade ja lugude mitmekesisuse“", samas kui tekkivad mõtteseosed „võtavad paradoksaalselt ühemõttelisi vorme“ iga üksiku külastaja jaoks (samas: 67-68; vt ka Basu, Macdonald 2007: 15).

Näituste ettevalmistamine toob alati kaasa vastuolulise mängu akadeemilise soliidsuse ja kunstilise mängulisuse, tunnete ja mõistete piirialal (Conte 2007: 44). Etnograafiliste manifestatsioonidena määratlevad ja kasutavad näitused ebamäärast tunnetuslikku ala, otsides midagi muutlikku ja hämmastavat. Filosoofilised muuseumid julgustavad külastajaid mõistma igasuguse inimliku teadmise alusena taotluslikku kontseptuaalset ebamäärasust. Sellised muuseumid näitavad kultuuri arengu järjepidevust ja katkendlikkust, enesemääratlemise viiside ja kultuurilise omapära muutlikkust. Etnograafiamuuseumid ühendavad inimesi ning määratlevad sotsiaalse sünteesi kokkupuutepunkte, muutes suhteliseks vahetud reaktsioonid ja muljed. Lõplikest selgitustest hoidumine on vajalik selleks, et avastada maailma mitmekesisus ja esitada mõtlema panevaid küsimusi. (Samas: 44-47)

Soome-ugri püsinäitusega seoses toimunud arutelude ja mõtiskluste kontekstis tuli meil seega esmalt otsustada, kuidas komplekteerida näituse töörühm ning millistest üldistest tunnetuslikest põhimõtetest lähtuda näituse kontseptsiooni väljatöötamisel. Samuti mõtlesime läbi ERMi soome-ugri uuringute ja näituste arenguloo, millesse meie koostatav väljapanek pidi paratamatult asetuma. Taolised arutlused ja kaalutlused olid laiahaardelised ja abstraktsed, ent tuli hakata astuma ka käegakatsutavamaid samme. 


\section{„Vaja on soome-ugri püsinäituse kontseptsiooni, kogud kannatavad kõik välja"s}

Üheks soome-ugri väljapaneku koostamise probleemiks oli seos näituse ja ERMi kogude vahel. Suurte kultuuriajaloomuuseumide püsiekspositsioonide puhul eeldatakse üldiselt, et "näitused peaksid põhinema eelkõige nende endi kogudel“ (Runnel 2015: 109). Seda suundumust peetakse muuseumimaailmas iseenesestmõistetavaks. Vladimir Arsenjev osutab samale tendentsile, mille kohaselt ajutiste näituste puhul lahendatakse fondide esinduslikkuse probleem tavaliselt muuseumidevahelise eksponaatide vahetuse kaudu. Ent püsinäituste jaoks peab muuseum auasjaks oma fondide esinduslikkuse rõhutamist. Selle põhimõtte järgimisest „,sõltub muuseumi eneseteostuse võimalus iseseisva institutsioonina. See toimub vastavalt muuseumi püüdluste tasemele ja kooskõlas asutuse staatusega kultuurisüsteemis" (Arsenjev 2007: 12).

Soome-ugri püsinäituse kontseptsiooni läbitöötamise lähtepunktiks on olnud ERMi kogu. Näituse ettevalmistamise algfaasis valmisid eraldi tekstiili- ja puitesemete nimekirjad, üksikute rahvaste puhul aga ka soome-ugri tudengite abil koostatud etniliste (handi, komi, mansi, mari, mordva, udmurdi, saami, vepsa) esemekogude süstematiseeritud nimekirjad-tabelid (koos eseme omakeelse nimetuse, eseme kogumise ja kasutamise andmetega). Selleks ajaks olid digiteeritud ka jooniste kogu, soome-ugri puitesemed, kindad ja vaibad ning osaliselt foto- ja videoarhiivid. Samas esitasid ERMi esemekollektsiooni maht ja eripära (lõviosa ERMi soome-ugri kogudest pärineb 20. sajandi keskpaigast ja on seotud argielu ja -tegevustega) meile ka spetsiifilisi väljakutseid. Võtsime eesmärgiks näidata soomeugrilasi ja samojeede läbi suhteliselt tavaliste asjade, tuua nad esile tavalisuse kaudu. Etnograafilise näituse ettevalmistamisel sõltub kuraatori tõlgendus algusest peale esemetest ja muudest muuseumi kollektsioonis leiduvatest materjalidest, mis iseenesest piirab vaba tõlgenduse ruumi. Samas kannavad olemasolevad kogud erinevate kogujate põlvkondade ideoloogiaid ning näituse tegemise käigus võib kuraator veel ka materjali juurde koguda, mis teeb sõltuvuse olemasolevast vähem ühemõtteliseks (vt Karm 2009: 473-474).

See pole aga lihtne ülesanne: näidata külastajatele, et tavalistes asjades peitub tähendusrikas etnograafiline maagia. Kuraatorite nägemus ekspositsioonist põrkus kohe alguses kujundustiimi ideega näidata müütilist minevikulist ja seega eksootilist soome-ugri maailma. Nii ei pakkunud näituse esialgsele peakunstnikule Peeter Lauritsale „materiaalse kultuuri suunas kreenis näitus [---] kosmilist dimensiooni ja usundilist allusiivsust" (Laurits 2017: 61) ${ }^{9}$ ja ta ei saanudki meie kontseptsiooni omaks võtta ning taandas end pärast aastast koostööd näituse tegemisest.

[8] ERMi teaduri Piret Õunapuu esitatud mõte ümarlaual „Kas ja millist hõimurahvaste püsinäitust vajab Eesti Rahva Muuseum uues peahoones Raadil?“, oktoober 2006.

[9] Samas näituse fotopannoode autorina märgib Laurits, et suurt huvi pakkus talle just volga rahvaste saali suletud õue konstrueerimine, mis oli tema jaoks ka kõige keerulisem saal kogu ekspositsioonis (Laurits 2017: 61). 


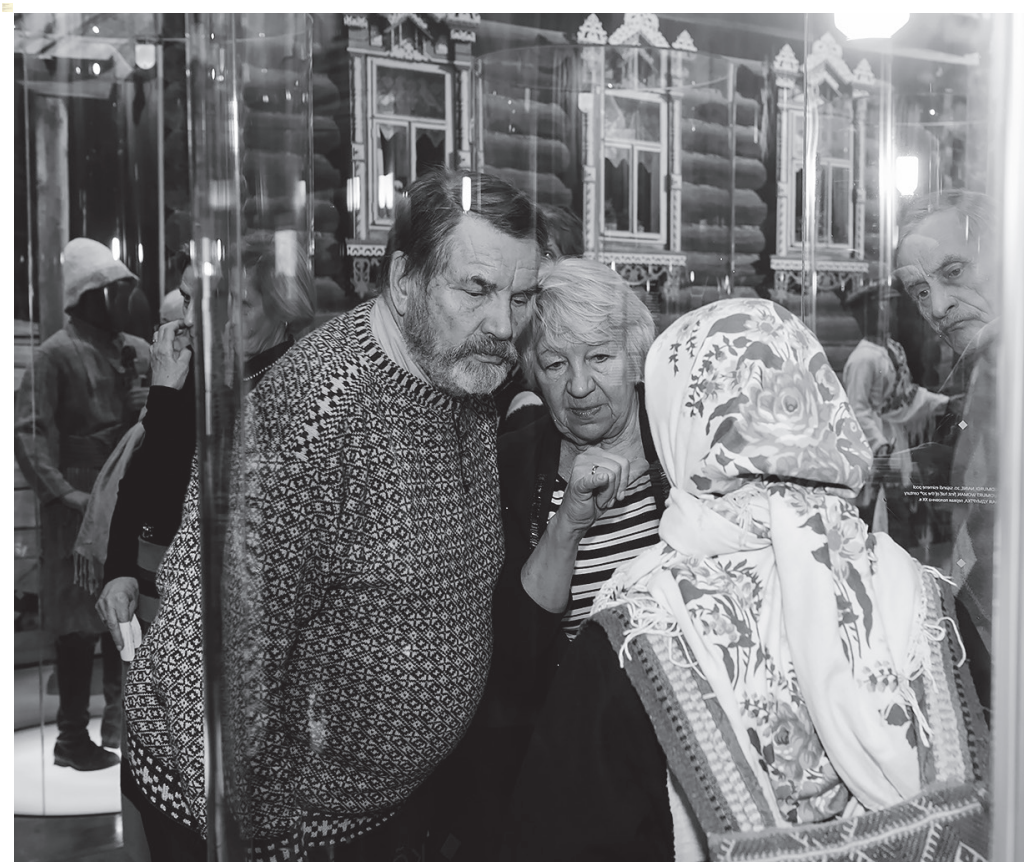

Näitusekülastajad volga rahvaste saalis eksponaate uurimas.

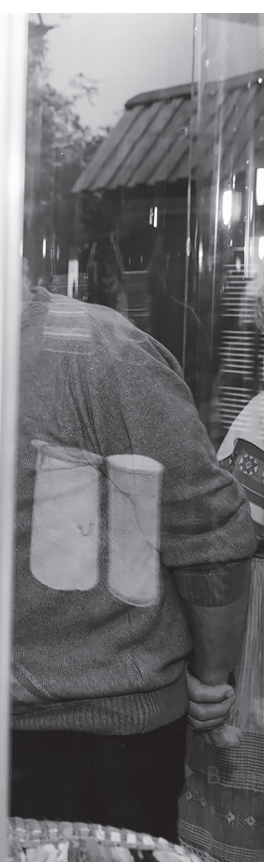

Foto: Arp Karm, 2016

Arutluste ja vaidluste tulemusena õnnestus kuraatoritel siiski teadvustada nii endale kui ka kujundajatele (JanKen Wisespace'i arhitektidele ja 2010. aastal meeskonnaga liitunud Velveti disaineritele), et igapäevase näitamine muuseumiruumis pakub uut ja huvitavat väljakutset, sest argikultuur on see, mida inimesed pidevalt kogevad ning millel rajanevad nii inimeste maailmapilt, mütoloogia kui ka esteetilised eneseväljenduspraktikad. Kujundajate ümbersõnastatuna sai läbivaks kontseptuaalseks suunaks „,argielu sügavus - museaalide, moodsa tehnoloogia, disaini ja arhitektuursete lahenduste abil kajastada argielu olustiku taga peituvat inimlikku soojust, traditsioone, lihtsaid tõekspidamisi ja elutervet huumorit" (kujundustoimkonna koosoleku memo, 17.02.2012; vt ka Mutso 2013). Näituse tegemisele tagasi vaadates on sisearhitekt Jan Graps näituse toimkondade koostöö arengut meenutanud üksteisemõistmise pideva kasvu taustal: „Näituse kujundusliku fookuse täpsustamise ja küpsemise käigus sai aina enam selgeks, et liigset tähelepanu pole tarvis pöörata eksootiliste tõlgenduste otsimisele mütoloogiast ja loitsudest, vaid kogu maagia sünnib meie silme all, igapäevaste tegevuste käigus, elulistes situatsioonides." (Männik, Kirsfeldt, Graps 2017: 93; vt ka Kuidas peaks... 2017)

Samas säilitasid nii sisu- kui ka kujundustoimkond oma lähenemisviisis adekvaatse autonoomia määra. Disainibüroo Velvet loovjuht Kristian Kirsfeldt sõnastas saavutatud disaini, arhitektuuri ja etnograafia harmoonia erinevate tunnetuskihtide lisamisena: „Graafilise disaini, nii nagu ka arhitektuurse sisekujunduse eesmärk oli luua ajaloolise ainese ümber uus, selgelt tajutav ekspositsioonikiht, mis on seo- 
tud, kuid ei segune etnograafiliste eksponaatidega“ (Männik, Kirsfeldt, Graps 2017: 93; Kuidas peaks... 2017).

Soome-ugri näituse disaini seostasid kujundajad etnofuturistliku ideoloogiaga. Etnofuturism on 1980. aastate lõpul Eestist alguse saanud ning soome-ugri pärandist lähtuv kõikehõlmav kultuuristrateegia. „See säilitab arhailised kultuurilise mitmekesisuse mustrid, põimides ürgse traditsiooni tänapäevasele ja tuleviku kultuuriväljale. Näituse disainimeeskonnale tähendas see ajalooliste "graafikate" - mustrite, vaiba- ja vöökirjade, peremärkide ja kaljujooniste - „,sissehingamist" ja moodsa käsitluse „väljahingamist.““ (Kuidas peaks... 2017)

Sisearhitektide, kunstnike, filmitegijate ja teiste asjaosaliste roll näituse tegemises oli väga suur, ületades ootused ja kujutlused, mis etnograafilisel toimkonnal töö alguses olid. „Uurali kaja“ ettevalmistamisega seotud 200 inimesest oli muuseumitöötajaid vaid näputäis. Seega oli ERMi koostööpartnerite sujuv koostöö näituse ettevalmistustööde laabumiseks möödapääsmatu. Ehkki vaidlusi oli toimkondade vahel omajagu, suutsime lõppeesmärgi poole suundudes teha omavahel pidevalt vastastikku sarnaselt mõistetud loomingulisi kokkuleppeid.

\section{„Uurali kaja” kontseptsioonist}

ERMi soome-ugri uurimistöö suundumuste ja partneritega toimunud läbirääkimise tulemusel arendasime välja näituse põhiidee ja lihvisime ning nüansseerisime seda väljapaneku ettevalmistamise käigus. Näitus valmis mitmes saalis kahel korrusel $1100 \mathrm{~m}^{2}$ pinnal. Pidasime meeles tõsiasja, et põlisrahvaste kultuuri käsitletakse tavaarusaamade kohaselt loomuliku, autentse ja justkui „tänapäevase moodsa elu negatiivsetele tagajärgedele alternatiive esitavana" (Mathisen 2004: 17). Meie eesmärk oli esitleda soome-ugri rahvaid normaalsete inimolenditena, kellel on omapärane kultuuripärand. Näituse toimkond hoidus ülerõhutamast soomeugrilaste eksootilist ja müstilist kuvandit ning püüdis demonstreerida asjaolu, et nende kultuur annab alust mõtisklemiseks kultuuridevaheliste inimlike väärtuste üle.

Kuraatorite toimkond otsustas keskenduda näivalt tavalistele esemetele ja tegevustele soorollide prisma kaudu. Näituse keskne idee põhineb naiste ja meeste igapäevaste tegemiste ja maailmamõistmise erinevuste mängul. Taoline kontseptuaalne valik võimaldas hoida näituse põhijoone lihtsa, ent samas ka ühiskondlikult olulisena. Soolise võrdõiguslikkuse küsimused on Eesti avalikkuses kasvava tähtsusega teema (Karm, Leete 2015: 114). Leidsime, et etnograafiline väljapanek saab seekaudu olla dialoogis ühiskonna arengu ühe tulipunktiga. „Uurali kaja“ kultuuriline intriig seisneb tänapäevase lääne ühiskonna ja traditsiooniliste soomeugri soorollide tunnetuslike kokkupuutepunktide ja konfliktikohtade kajastamises. Ehkki paljud põliskultuuri reeglid määratlevad soorolle rangelt, leidub rahvapärimuses lugusid, mis näitavad naiste ja meeste suhteid pigem groteski ja ambivalentsuse võtmes.

Kuraatorite tähelepanu oli ka sellel, milliseid võimalusi on soome-ugri ühiskonnad pakkunud naistele ja meestele eneseteostuseks, võimaldamaks teha asju, mida nad teha tahavad; naise ja mehe rolli spetsiifika seotusel eluviisiga; naise ja mehe 
rollide dünaamikal kultuurimuutuste kulgedes. Teisiti öelduna - naiste ja meeste tegevusväljade erinevust ei põhjendata hierarhiliselt ega seksistlikult, vaid sotsiaalse eluviisi, tavade ja laiema ühiskondliku konteksti muutumisega.

Lisaks näituse teema üldinimlikule loomusele ja ajastuspetsiifilisele avalikule tähelepanule soorollide teemale toetas meie kontseptuaalset valikut ka ERMi kogude koostis. Kollektsiooni põhimass on jagatav soolises võtmes ning seega võisime olla kindlad, et materjalipuudus meid ei ähvarda. Samas sai soorollide kaudu käsitleda laia ringi kultuuripraktikaid, sest ka päriselus on pea kõik seotud naiste ja meeste tööjaotuse ja kultuuritunnetuse eripäradega. Taolise elulise lähenemisviisiga püüdsime muuta muuseumi metafoorselt „aktuaalsete ühiskondlike probleemide lahendamise pesaks" (Arsenjev 2007: 14).

Soome-ugri näitusega seotud kontseptuaalseid uitmõtteid visandades seostus dialoogi metafoor meie jaoks erinevate tunnetuslike pidepunktidega. Kõik see ei pruugi näitusel eksplitsiitselt ilmneda, ent mõttelise ja meelelise tajuilmana põhineb väljapanek sellistel abstraktsetel skeemidel või diskursiivsetel seostel. Olukorras, kus näituse konkreetne sisu veel puudus, moodustasid just need kogu tunnetusliku pagasi, millest väljapanekut konkretiseerima hakkasime.

Esiteks lähtusime nähtavuse ja nähtamatuse küsimusest etnograafide ja soomeugrilaste dialoogis. Aastakümneid kestnud etnograafilises dialoogis on soome-ugri naised olnud nähtaval, mehed nähtamatud. Naised on kandnud põlisust ka kaasaegsemasse maailma, meeste kaudu on tulnud soomeugrilaste ellu modernsus, uuendused. Naiste olek on silmapaistvamalt arhailine, nende tegevused aga kodule lähedasemad, võõrale, külla saabunule lihtsamini tajutavad ja nähtavamad. Naised on olnud altimad teadlastega suhtlema. Nad armastavad rohkem rääkida ja seega jäädvustub nende kuvand kultuurist kergemini. Aga kus vähegi võimalik, püüdsime esitleda just meeste varjatumat, ehk tõrksamatki sõnumit.

Teiseks kaalusime ka etnograafilise tõsiasjalikkuse ja haaramatuse dimensioone. Soome-ugri rahvad on tõsiasjalikult olemas, nende esemed on konkreetsed, nähtavad ja teatud juhtudel ka katsutavad (kuigi näitusel põhiosas mitte), midagi on konkreetselt välja öeldud ja kirja pandud, midagi on pildistatud ja joonistatud, aga midagi muud jääb sellesama konkreetsuse juures ikkagi lahtiseks, õhku, midagi jääb tõlgendamiseks ja mõistatamiseks. Tõlgendus on haaramise sulguv ring (kui hermeneutilisemalt väljenduda), aga mõistmine kujuneb samaaegselt ka niimoodi, et äratundmised toimuvad teisel pool, nagu mööda Möbiuse lehte kulgedes või kohevas lumes ringe tehes - minna saab, teist samasugust ringi teha saab ja ei saa.

Kolmandaks otsustasime kujutada soome-ugri rahvaste kultuuride aspekte läbi meeste ja naiste suhete huumoriprisma. Näituse idee põhimõtteks pole näidata, nagu oleks soomeugrilastel naiste ja meeste suhted põhimõtteliselt erinevad teiste rahvaste omadest. Alusmõte on olnud pigem see, et kui mõelda tavapäraselt ümbritsevast kultuurilisest maailmast võrdse kohtlemise paradigma valguses, siis tuleb tunnistada, et soome-ugri põliskultuurides on meeste ja naiste rollid palju traditsioonilisemalt, selgemalt ja binaarselt opositsioonilistena määratletud, kui tänapäevases Euroopas kombeks on saanud. Teisalt on see vanaaegne sugupoolte võitlus ja ühtsus, st dialektika palju loomulikum (st kultuuri loogikaga hästi seotud). Naiste ja meeste sotsiaalse käitumise erinevus on selgelt mõtestatud ning eluline, aidates 
kaasa kultuurilisele ellujäämisele. Nende suhete lahkamine huumorivõtmes pidi meie lootuste järgi katma kogu näituse tunnetusliku ambivalentsuse võrgustikuga. Seega lootsime naljatamisega kaasa aidata sellele, et väljapanek ei tunduks külastajatele ühemõtteline ning tõlgendustele suletud.

\section{Ekspositsiooni mitmekihilisus}

Näituse tegemise algfaasis läbimõeldud kontseptuaalsed momendid ning kogude sisu on muidugi ekspositsiooni kujunemisel määravad. Ent ilma atraktiivsete meetmete rakendamiseta pole näitust siiski olemas. See oli kõigile tegijatele samuti algusest peale selge, et külastajate näitusesse sissetõmbamise atraktiivsed viisid aitavad kaasa meelelisele avatusele ja tõlgenduslike väljakutsete esiletulekule (vt ka Tšernenko 2006: 117-120). Samas pole esitlusmeediumite mitmekesisuse põhimõttest abi ilma konkreetsete ideedeta, kuidas ja milliseid külastajate tähelepanu püüdmise vahendeid kasutada.

Selles suhtes on iseloomulik „Uurali kaja“ multifilmide tegemise protsess. Kui me näituse koostamisega alustasime, polnud etnograafidel ega kujundajatel vähimatki ideed taolise lahenduse osas. Mõte põimida soomeugrilaste lood näituse ekspositsiooni tekkis Art Leetel 2010. aasta oktoobris. Idee lähtus vajadusest näituse stseene mitmekesisemalt mõtestada, omavahel siduda ja lisada väljapanekule rohkem tunnete kihte. Näituse üldise teema ja meeleoluga kokkukõlamiseks pidid need lood olema huumori ja iroonia kaudu seotud igaveste proovikividega naiste ja meeste suhetes. Rahvaluule ei hooli tihtipeale mingi ajahetke konventsioonidest ja on nendega juhuslikus, entroopilises suhtes. Lootsime, et ehedad lood annavad näitusele elavuse; et nende kaudu on võimalik soome-ugri pärimuse allikast ammutada argumente naiste ja meeste suhete hämarast olemusest, mis kuraatorite sõnastuses, teaduspõhise seletusena poleks nii vahetu. Lood pidid kaasa aitama sügavama tasandi kooskõla saavutamisele kogu näituse ulatuses. (Leete 2017: 6)

Näituse kujundajatega arutasime erinevaid viise, kuidas neid lugusid esitada. Jan Graps ja Ken Ruut avaldasid seejärel Sirbi veergudel arvamust, et soome-ugri näitus peab maailma uudisekünnise ületama ning seetõttu võiks muinasjutte lugema kutsuda näiteks Anthony Hopkinsi. Kuigi sisearhitektid tutvustasid seda lihtsalt kui kõige meeletumat visiooni (Mutso 2013), tuli näituse toimkonna liikmetel seepeale vastata ajakirjanike küsimustele Hollywoodi staaride kaasamisest „Uurali kaja" filmide valmimisse. ${ }^{10}$

Lõpuks tundus mõte animafilmidest kõige sobivam lahendus. Jätsime filmitegijatele võimalikult palju loomingulist vabadust. Soome-ugri lugudel pole ranget esitamis- ja arusaamisviisi. Teisalt püüdsime oma teadmistele ja vaistule toetudes siiski arvestada sellega, kuidas soomeugrilased ise neid lugusid tajuda võivad. Mõni kogemata ekslikult esitatud etnograafiline detail või maailmapildi üksikasi võib kogu mulje filmist rikkuda. Lootsime, et soomeugrilaste jaoks ei muutu filmid

[10] Art Leete intervjuu põhjal ilmus Eesti Ekspressis 5. märtsil 2013 artikkel „Hollywoodi staarid võetakse Eesti Rahva Muuseumi teenistusse?" 


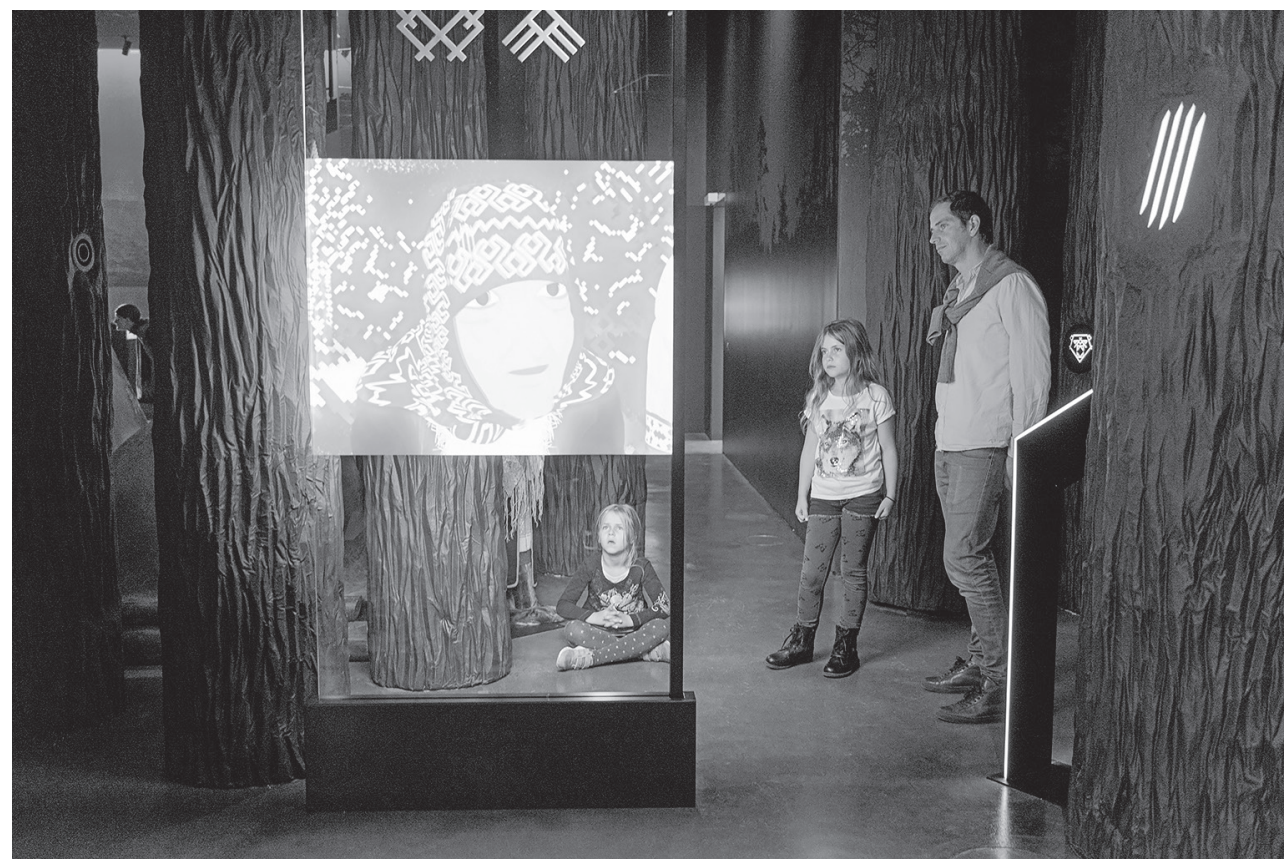

Koostöös Eesti Joonisfilmiga valmis 9 animafilmi, mille aluseks on soomeugrilaste rahvasuust pärinevad lood naiste-meeste suhetest. Näitusekülastajad mansi looga tutvumas (filmi autor Martinus Klemet, kuraator Art Leete).

Foto: Berta Vosman, 2016

naeruväärseks või solvavaks. Kõik valitud lood sisaldavad algsel kujul annuse huumorit. (Leete 2017: 6)

Lõpplahendusena jäi kehtima põhimõte, et ekspositsioonis on kesksel kohal museaal, multimeedia toimib lisavahendina. Samas ei tähendanud see, et interaktsioon ja meedia peaksid olema esemete varjus. Eriti oluline oli näitusel tervikliku meelelise kogemuse pakkumisel helikujunduse roll. „Uurali kaja“ helimaastikku kavandades seati eesmärgiks, et „oleks võimalik heli maha mängida viisil, mille sarnaselt ta kõige enam ka looduslikus keskkonnas kõlada võiks" (Tulev 2017: 97). Seetõttu paigutati heliallikad näitusel nii, et külastajal tekiks võimalikult loomulik meeletaju efekt. Suur osa helisid salvestati loodusest spetsiaalselt „Uurali kaja“ väljapaneku jaoks (samas). Intensiivse töö tulemusena valmis maailma suurim näituse helimaastik (140-kanalilise heli edastamiseks kasutatakse 126 kõlarit), mis on kindlasti üks ekspositsiooni tõmbemomente. (Kuidas peaks... 2017)

Tihtipeale on näitusel heli ühendatud visuaalse meediaga, nagu näiteks kohe näituse alguses algava sinise valgusjõe puhul, mida kujundajad kirjeldavad ühtaegu moodsa ja hubasena:

Läbi terve näituse voolab helendav sinakas LED-valgusjõgi, mida mööda külastajad ühest ruumist teise sammuvad. Jões ujuvad animeeritud kalakesed, mis reageerivad külastajale, kes 


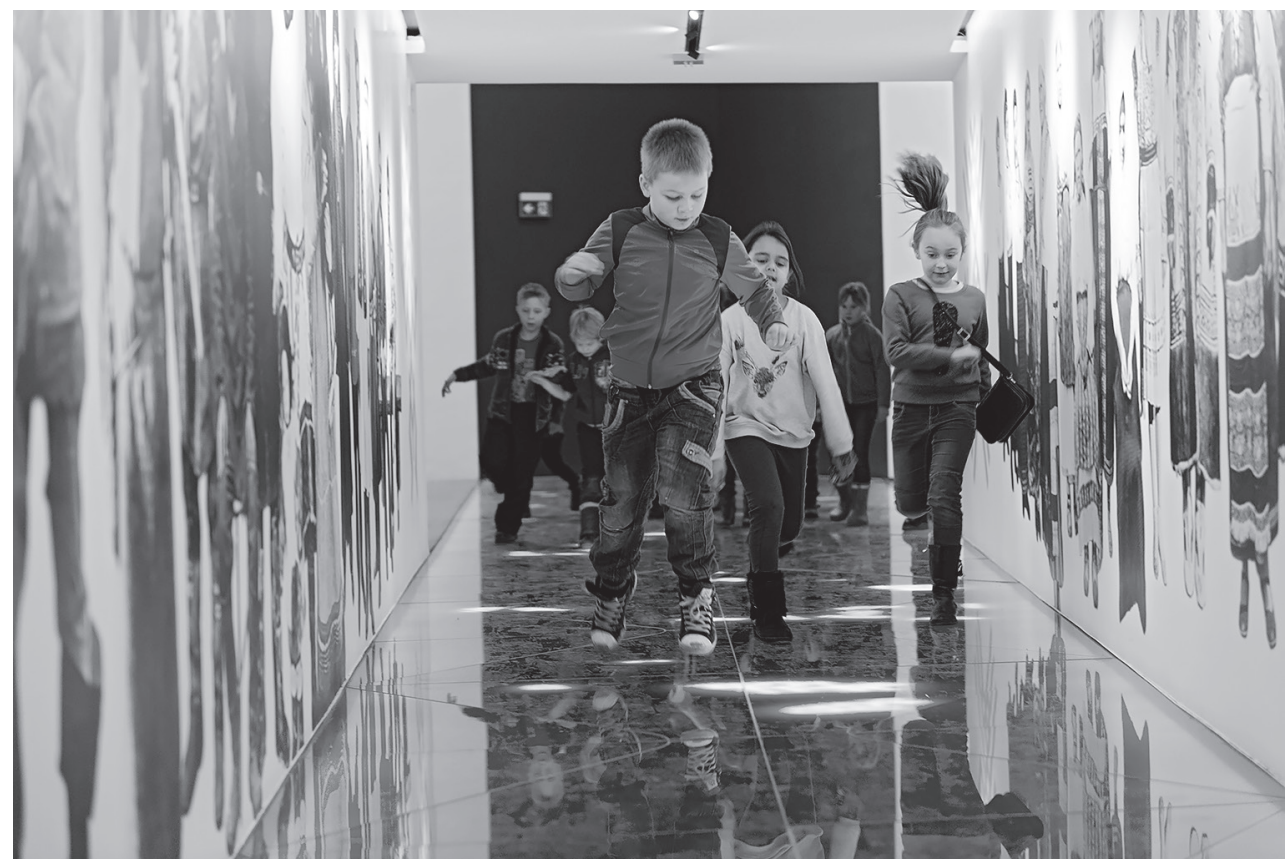

Laste suureks lemmikuks osutus valgusjõgi, mille klaaspinna all pulseerivad kalad. Valgusjõgi toimib ühtlasi soome-ugri ekspositsiooni teejuhina. Tartu Raatuse Kooli päev ERMis novembris 2016.

Foto: Anu Ansu

jõepinnale astub: esmalt ujuvad eemale, ent jalutajaga harjudes naasevad külastajate jalgade ümber tiirutama. Näituse helilahendus lisab valgusjõele loomulikkust: kuulda on tõelise oja vulisemist ja vee laksumist kivide vastu. (Kuidas peaks... 2017)

Küsimus polnud ainult üksikasjades, mis loovad erilist meeleolu ja tundeid teatud paikades. Ekspositsiooni tajuraamistiku moodustas kõikehaarav tunnete keskkond, mille üldine meeleolu dünaamika oli paika pandud väljapaneku kaudu. Jan Graps selgitas näituse üldise interaktiivse tausta lahti järgneval moel:

Neljale saalile on loodud võimalikult tunnuslik keskkonnamiljöö ja saalid on asetatud ka nn ajateljele: esimeses saalis on hommik ja kevad, järgmises saalis on suvi ja keskpäev jne. Hommikusaali seintel on udused orunõlvad ja metsapanoraamid tõusva päikese kiirtes, rõhuasetus on siin küttimisel. Järgmises saalis on sellele vastukaaluks keskpäevane selge ja valge pulmapeo melu. Kolmas saal Läänemere saal on loomuomaselt sügisene ja mõtlik, seal on alepõllunduse, merekalastuse ja sauna teema. Viimases saalis on talveöö. (Mutso 2013)

Graps kirjeldab ka näituse interaktiivse komponendi intensiivsuse astet kui tagasihoidlikku ning rõhutab püüdu olla digitaalsete lahendustega tundlik ja võimalikult varjatud: „Oleme jõudnud lahenduseni, kus kogu virtuaalne osa on hästi intuitiivne: monitor seinas on vaikolekus, kaob seinapildi sisse, aga inimese lähenedes reageerib, tekib võimalus suhestuda ekraaniga. Virtuaalne maailm ei ole pealetükkiv, pigem taustal." (Mutso 2013) 


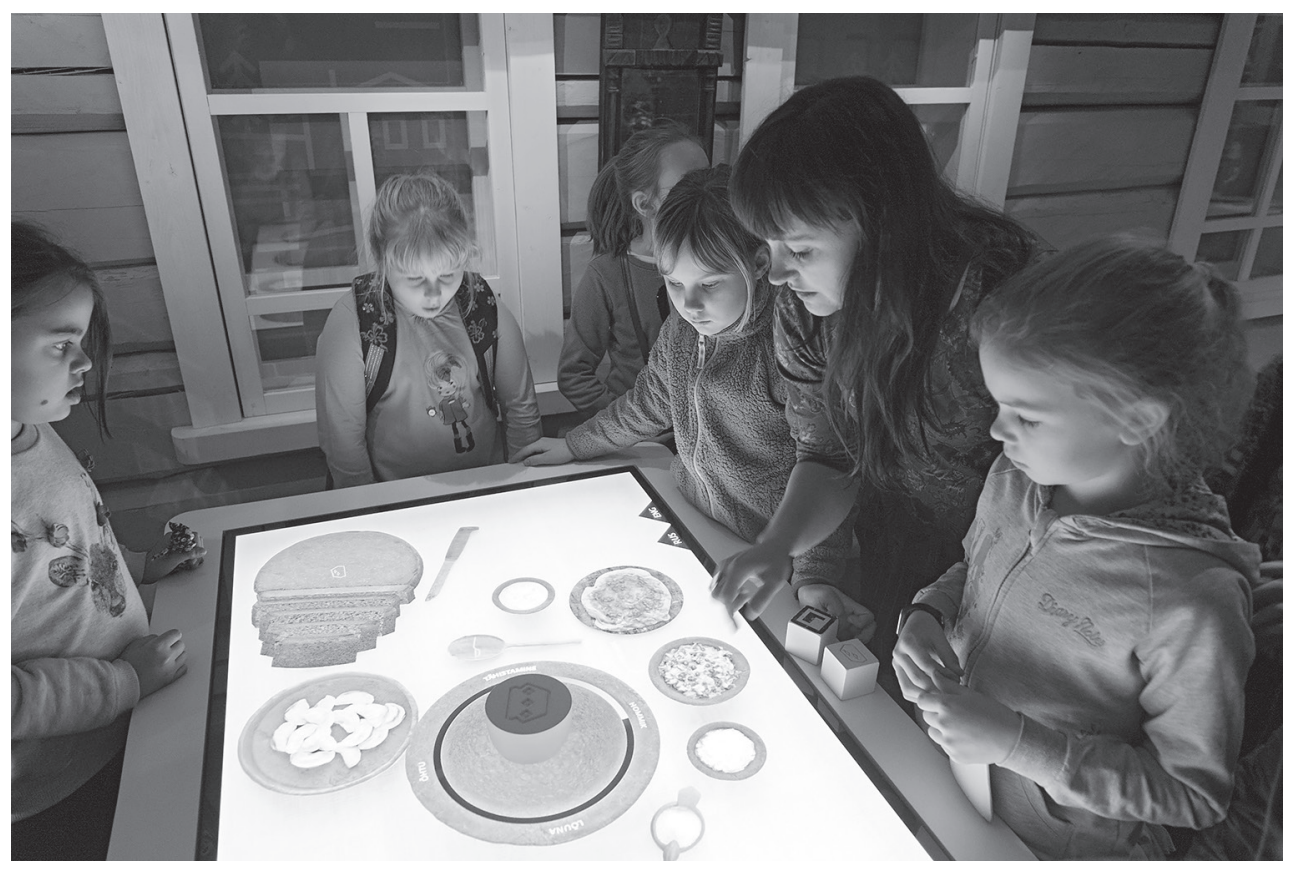

Söögilaud komi tares. Kõik näituse interaktiivsed lahendused on tehtud nii, et ka kõrvaltvaataja saab aru, milles mäng seisneb - ei pea tingimata ise olema mängijaks. Tartu Raatuse Kooli päev ERMis novembris 2016.

Foto: Anu Ansu

Näitusel on väljas 48 multimeediainstallatsiooni (puutetundlikud ekraanid, animafilmide paneelid, valgusjõgi, liikumistundlikud mikrofonid ja muu). Võimalik on kogeda lõhnu, helisid, soojust ning mitmesugust valgust. Üldise emotsionaalse dünaamika omapärasemaid loojaid on interaktiivne komi köögilaud, kus on võimalik uurida toiduga seotud vanasõnu, mõistatusi, tutvuda rahvapäraste retseptide ja einekordade kirjeldusega. Digitaalsed interaktsioonid jäävad selgelt kunstlikeks, ent loovad üheskoos etnograafiliste esemete ja installatsioonidega siiski kummastava loomulikkuse õhkkonna ning toetavad loodusläheduse ja kodususe tunnet, mis kandub läbi kogu ekspositsiooni. „Uurali kaja“ edu üheks põhjuseks võibki olla tehnilise arengu avangardis olevate lahenduste põimimine retroliku esteetikaga. Ajad muutuvad, kuid mõned asjad jäävad samaks. Pole võimatu, et Manninen jääks meie näitusega väga rahule. Nii võib oletada, kui lugeda tema 90 aasta taguseid muljeid Venemaa muuseumitest:

Wene muuseumid [---] tarvitavad mudeleid väljapanekuteks vähe. Kui vähegi võimalik, seatakse ka suured asjad originaalidena nähtavale. See nõuab suuri ruume, avaraid saale. Moskva muuseumis on Siberi ja Kesk-Aasia rahvad ühes ainukeses suures saalis. Sellesse on mahutatud terve hulk kappe, näiteseinu ja päriselanikkude elamuid loomulikus suuruses: nii jakuutide talvejurta, ostjakkide tohupüstkoda ja selle väljaspool mõnesuguseid suuremaid kalapüügiriistu, edasi samojeedide talvekoda, kaetud põhjapõdranahkadega, burjaatide valge vildiga kaetud telk ja umb. samasugune kirgiisidelt. Elamutes on asjaomane sissevaade ning 
ka inimesed, loomusuuruses mannekeenid. Üldse on Moskva rahvastemuuseumis [Мyзеŭ народоведения] pandud suurt rõhku loomulikus suuruses stseenidele, mis kujutavad peale elamuste inimeste rühmasid või üksikuid inimesi, sagedasti mingi töö juures. Et mainida mõningaid näiteid soomesugu rahvastest nimetagu tscheremissi meest ja naist, kes on ladunud kuhikukujulise kuivatisrehe latid rukkivihkusid täis, mille järele mees, tõusnud lähedal seisva kärbise otsa, parajasti tõmbab köit kuhiku ümber, et vihud ei saaks maha kukkuda. Teisel stseenil on näha tscheremissi mesinik, kes ronib puu otsa, kus tal puuõõne sees on mesila. Niisuguseid stseene on seni alles mõningaid, kuid kavatsus väljapanekute laiendamisel neile ikka rõhku panna. Erapooletu aroustuse seisukohast tuleb mõtet kiita. Suurele üldsusele teevad sellased stseenid muuseumi elavaks. Niisugused loomusuuruses etnograafilised vaated jäävad muuseumi külastajale tingimata meele. (Manninen 1928)

Seda on raske öelda, kas tõesti taoline moodsa ja klassikalise lähenemise lõimimine on olnud ka tegelikult näituse edu tunnetuslik tagatis. See, et „Uurali kaja“ väljapanekus on mitmel tasandil ühendatud arhailine ja modernne, polnud alguses plaanis. Ent ajapikku kujunes taoline lähenemine justkui iseenesest näitust läbivaks jooneks.

\section{Kokkuvõtteks}

Käesolevas töös oli meie peamiseks eesmärgiks analüüsida „Uurali kaja“ näituse kontseptsiooni. Kirjeldasime väljapaneku mõtestamise teoreetilisi lähtekohti ning praktilisija organisatsioonilisi asjaolusid(ERMikogud, näitusetoimkondadekoostöö problemaatika), millel oli näituse kontseptsiooni ja tegeliku ülesehitamise mõttes kaalu. Samuti uurisime väljapaneku interaktiivsete lahenduste problemaatikat, tuues esile nii kuraatorite kui ka kujundajate toimkonna liikmete seisukohti. Nagu ilmnes, jõudsid toimkonnad kontseptuaalsetes küsimustes harmoonilise teineteisemõistmiseni, ehkki vaadete sarnaseks lihvimiseks kulus mitu aastat.

Käesoleva uurimusega püüdsime reflekteerida näituse tegemist vahetult pärast valmimist. Midagi jääb meil selle ajalise distantsi puudumise tõttu ilmselt kahe silma vahele, ent mingid muljed ja mõtted saavad just seetõttu ka fikseeritud ega kao kohe kõikehaaravasse unustusse. Nii nagu meie jaoks oli uus sellise suure näituse tegemise kogemus, on ka selle ekspositsiooni valmimise üle mõtlemine meie jaoks enneolematu. Kogemuslikult ei oska me seda millegagi oma senises töös päris hästi võrrelda, mingisse isiklikku tunnetatud konteksti asetada.

Kui jälgida seni meie näitusele osaks langenud, põhiliselt positiivset tähelepanu (auhinnad ja tunnustused Eestis ja rahvusvahelisel tasandil, analüütilised käsitlused mitmetes väljaannetes ja sotsiaalmeedias), võib tööga rahul olla. Ometi jääb kohati mulje, et meid ikkagi ei mõisteta. Tõenäoliselt on see tunne tuttav paljudele kuraatoritele ja mida pikem on olnud ettevalmistus ja mahukam näitus, seda suurem on selle tunde tekkimise oht. Tahaksime siiski rõhutada, et näituse toimkonda ei tasu süüdistada mõtlematuses ega juhuslikes valikutes (nagu propageeriks me näiteks soolist ebavõrdsust). Oleme aastate jooksul näituse teema, erinevad väljapaneku osad ja tehnilised lahendused põhjalikult läbi arutanud ning asjad, mis näi- 
vad esmapilgul lihtsad, tõenäoliselt ei ole seda. Me muidugi mängime soorollide tõlgendustega (see on seotud ka näituse temaatikaga), ent süüvides peaks olema näha, et huumor ja iroonia käib kokkuvõttes mõlema sugupoole kohta ega ole ühemõtteline.

Aga kui leitakse, et näituselt on puudu olulisi asju, mida sealt on põhjust eeldada (näiteks põliskultuuride raske tänapäevase olukorra selget peegeldust) ning et selle asemele pakume romantiseerivat ülistamist, siis tuleb meil etteheidetega nõustuda. Ent mõelda tuleb ka sellele, et me ei püüdnud näidata soomeugrilaste kohta kõike olulist, vaid keskendusime ekspositsiooni kontseptuaalsele ühtsusele. Eeldasime, et ükskõik, millest see näitus ka pole, toimib ta niikuinii massiivse soome-ugri rahvaid toetava manifestatsioonina. Ja see patt jääb ka muidugi meie kõigi hingele, et püüdsimegi teha ilusat näitust.

Aastate jooksul on toimunud väga palju koosolekuid, arutelusid ning ka kirglikke vaidlusi erinevatel teemadel. Seades endale ambitsiooni teha maailma parim soome-ugri näitus, oleme samaaegselt olnud nii museoloogiliselt konservatiivsed kui ka lennukalt innovaatilised. Lähtudes oma valikutest, olemasolevast muuseumikogust ja näitusekülastaja heaolust, oleme püüdnud hoida tasakaalu näituse teadusliku ja emotsionaalse poole vahel. Põimides ühte sajandivanuseid muuseaale, interaktiivseid ekraane, heli-, lõhna- ja valgusinstallatsioone ning ootamatuid ruumilisi lahendusi, oleme püüdnud luua muuseumiruumi erilise keskkonna, mis pakuks külastajale mitmesuguseid elamusi ja soovi tulla siia tagasi. Muuseumikülastajate tagasiside ja head emotsioonid annavad põhjust arvata, et näitus on omaks võetud, et külastajal on siin hea olla ... et meeskonna valikud on osutunud õigeks.

Kohtumiseni näitusel!

\section{Allikad}

ERM A, nr. 1, s. 521. Eesti Rahva Muuseumi tegevuse ülevaade 1928/9 (1 apr. 28 - 31 märts 29)

\section{Kirjandus}

Agapova 2015 = Агапова, Дарья. 2015. От редактора. - Культура участия: музей как пространство диалога и сотрудничества. Ред.-сост. Д. Агапова. Санкт-Петербург, 8-11.

Arengukava $=$ Eesti Rahva Muuseumi Arengukava 2017-2010. http://www.erm.ee/et/content/arengukava-2017-2020 (viimati külastatud 15.08.2018).

Arsenjev 2007 = Арсеньев, Владимир Романович. 2007. Кризис музеев? Кризис этнографии? Кризис цивидизации? - Антропологический форум № 6, 9-19.

Auasi 2008 = Svetlana Karm, Marleen Nõmmela, Piret Koosa (koost). Auasi. Eesti etnoloogide jälgedes. Tartu: Eesti Rahva Muuseum.

Baranov 2004 = Баранов, Дмитрий Александрович. 2004. Выставка «Парад народов»: вещь в музейном пространстве. - Этнографическое обозрение № 5, 236-240. http://journal.iea.ras.ru/archive/2000s/2004/Baranov_2004_5.pdf (viimati külastatud 15.08.2018). 
Baranov 2017 = Баранов, Дмитрий Александрович. 2017. Очем модчат вещи. - Российская антропология и "онтологический поворот“, отв. ред. С. В. Соколовский. Москва: ИЭА $\mathrm{PAH}, 33-83$. http://static.iea.ras.ru/news/Ontological\%20Turn.pdf (viimati külastatud 15.08.2018).

Basu, Paul. 2007. The Labyrinthine Aesthetic in Contemporary Museum Design. - Exhibition Experiments, edited by Sharon Macdonald and Paul Basu. Malden, MA; Oxford; Carlton: Blackwell Publishing, 47-70.

Basu, Paul; Sharon Macdonald. 2007. Introduction: Experiments in Exhibition, Ethnography, Art, and Science. - Exhibition Experiments, edited by Sharon Macdonald and Paul Basu. Malden, MA; Oxford; Carlton: Blackwell Publishing, 1-24.

Bogaart 1983 = Богаарт, Нико. 1983. Изменение концепции этнографического музея. Muиseum. Этнографические музеи. № 139 (том XXXV, № 3), 13. http://unesdoc.unesco. org/images/0012/001273/127338rb.pdf (viimati külastatud 15.08.2018).

Belcher, Michael. 1991. Exhibitions in Museums. Leicester Museum Studies Series. Leicester and London; Washington, DC: Leicester University Press; Smithsonian Institution Press.

Clifford, James. 1988. The Predicament of Culture: Twentieth-Century Ethnography, Literature, and Art. Cambridge; Massachusetts, MA; London: Harvard University Press.

Conte, Francis $2007=$ Конт, Франсис. 2007. От этнографического музея к музеям общества. Размышления по поводу французского опыта. - Антропологический форум № 6, 41-47.

Crew, Spencer R.; James E. Sims 1991. Locating Authenticity: Fragments of a Dialogue. Exhibiting Cultures: The Poetics and Politics of Museum Display, edited by Ivan Karp and Steven D. Lavine. Washington, WA; London: Smithsonian Institution Press, 159-175.

Ernits, Villem 1926. Hõimutöö põhiküsimusi. - Eesti ja Soome üliõpilaskondade hõimualbum I / Suomen ja Eestin ylioppilaskuntien heimoalbumi (toimetus Villem Ernits jt). Tartu: Postimees, 89-103.

Fofin 2011 = Фофин, Александр Иванович. 2011. Музей как медиативное пространство диалога культур: Парижский „Музей на набережной Бранли“. - Magister Dixit № 1, 159-167. http://cyberleninka.ru/article/n/muzey-kak-mediativnoe-prostranstvo-dialogakultur-parizhskiy-muzey-na-naberezhnoy-branli (viimati külastatud 15.08.2018).

Foorum 2007 = Форум "Этнографические музеи сегодня“ 2007. - Антропологический форум № 6 (Вопросы редколиегии), 8.

Harvey, Penny, Hannah Knox 2014. Objects and Materials: An Introduction. - Penny Harvey, Eleanor Conlin Casella, Gillian Evans, Hannah Knox, Christine McLean, Elizabeth B. Silva, Nicholas Thoburn, Kath Woodward (toim). Objects and Materials: A Routledge Companion. London, New York: Routledge, 1-17.

Heinapuu, Andres 2007. Hõimusolidaarsus aitab jääda iseendaks. - Fenno-Ugria. Horisondi lisaväljaanne, 1 .

Hollywoodi staarid võetakse Eesti Rahva Muuseumi teenistusse? - Eesti Ekspress, 5. märts 2013). http://ekspress.delfi.ee/kuum/hollywoodi-staarid-voetakse-eesti-rahva-muuseumi-teenistusse?id=65748882 (viimati külastatud 15.08.2018).

Karm 2009 = Карм, Светлана. 2009. К 80-летию первой финно-угорской этнографической выставки в Эстонии, или Размышления куратора одного завершенного (?) проекта. - Финно-угры - славяне - тюрки: опьт взаимодействия (традиции и новации). Сборник материалов Всероссийской научной конференции. (Составление и общая редакция: А. Е. Загребин, В. В. Пузанов). Ижевск: Удмуртский институт истории, языка и литературы УрО РАН, Удмуртский государственный университет, 473-479.

Karm 2011 = Карм, Светлана 2011. Эхо Урала в Эстонском национальном музее, или музеологический аспект эстонского концепта „финно-угорский мир“. - Ежегодник финно-угорских исследований 3, ред. Н. И. Аеонов, А. Е. Загребин, А. В. Ишмуратов, 
Р. В. Кириллова, Д. И. Черашняя. Ижевск: Издательство Удмуртский университет, 98-110.

Karm, Svetlana; Art Leete. 2014. Eesti Rahva Muuseumi soome-ugri püsinäituse kujunemislugu. - Üve Maloverjan (toim). Soome-ugri sõlmed 2013. Tallinn: Fenno-Ugria, 70-77.

Karm, Svetlana; Art Leete. 2015. Ethics of Ethnographic Attraction: Reflections on the Production of the Finno-Ugric Exhibitions at the Estonian National Museum. - Journal of Ethnology and Folkloristics, Vol. 9, No. 1, 99-121.

Karp, Ivan 1991. Culture and Representation. - Exhibiting Cultures: The Poetics and Politics of Museum Display, edited by Ivan Karp and Steven D. Lavine. Washington, WA; London: Smithsonian Institution Press, 11-24.

Kirch, Marika. 2002. Eesti ja Euroopa identiteet. - Aune Valk (koost). Eesti ja eestlased võrdlevas perspektiivis. Kultuuridevahelisi uurimusi 20. sajandi lõpust. Tartu: Tartu Ülikooli Kirjastus, 87-101.

Kirshenblatt-Gimblett, Barbara. 1991. Objects of Ethnography. - Exhibiting Cultures: The Poetics and Politics of Museum Display, edited by Ivan Karp and Steven D. Lavine. Washington, WA; London: Smithsonian Institution Press, 386-443.

Konksi, Karin. 2009. Etnograafia muuseumina Nõukogude Eestis 1957-1991. - Eesti Rahva Muuseumi 100 aastat. Tartu: Eesti Rahva Muuseum, 250-355.

Kotilainen 2007 = Котилайнен, Эйя-Майя. 2007. Новые проблемы представления мировых культур в музее. - Антропологический форум № 6, 48-56.

Kuidas peaks ... 2017 = Kuidas peaks välja nägema maailma parim soome-ugri näitus? Uurali kaja - Eesti Rahva Muuseumi püsinäitus. https://medium.com/echo-of-the-urals/kuidas-peaks-v\%C3\%A4lja-n\%C3\%A4gema-maailma-parim-soome-ugri-n\%C3\%A4itusac0f5b0e4a7 (viimati külastatud 15.08.2018).

Laanisto, Lauri. 2016. Ümbernurgalugude jahil. - Eesti Rahva Muuseumi ajaveeb. http://blog. erm.ee/?p=9157 (viimati külastatud 15.08.2018).

Laurits, Peeter 2017. „Uurali kaja“ fotopanoraamide lugu: montaaž ja trükkimine. - Soomeugri sõlmed 2016, 59-64.

Leete, Art. 2017. Soome-ugri emandate ja isandate filmid. - Svetlana Karm, Art Leete, Priit Tender (koost). Uurali kaja: 9 animeeritud juttu soome-ugri naistest ja meestest. Tartu: Eesti Rahva Muuseum, 6.

Leete, Art; Svetlana Karm. 2015. Soome-ugri näitused. - Agnes Aljas, Jane Liiv (koost). Etteaste. ERMi näitusemaja 1994-2015. Tartu: Eesti Rahva Muuseum, 100-110.

Lehtinen, Ildiko. 2017. „Uurali kaja“ võrdluses soome-ugri rahvaste ekspositsioonidega mujal. - Soome-ugri sõlmed 2016, 65-68.

Manninen, Ilmari Justus 1924. Etnograafia tegevuspiiridest ja sihtidest Eestis. (Esiloeng, peetud 16.X.1924. a. Tartu Ülikoolis). - Eesti Kirjandus № 12, 527-537.

Manninen, Ilmari Justus Andreas 1928. Wene muuseumid. Etnograafilised muuseumid Leningradis ja Moskvas. - Postimees, 26. september. http://dea.nlib.ee/fullview.php?frames et $=3 \&$ showset $=1 \&$ wholepage=suur \&pid=s1177336\&nid=50395\&con=0; Postimees, 27. september. http://dea.nlib.ee/fullview.php?frameset=3\&showset=1\&wholepage=suur\&pid= s988619\&nid=50396\&con=0 (viimati külastatud 15.08.2018).

Mathisen, Stein R. 2004. Hegemonic Representations of Sámi Culture: From Narratives of Noble Savages to Discourses on Ecological Sámi. - Creating Diversities: Folklore, Religion and the Politics of Heritage. Studia Fennica Folkloristica 14. Edited by Anna-Leena Siikala, Barbo Klein and Stein R. Mathisen. Helsinki: Finnish Literature Society, 17-30.

Mutso, Margit. 2013. Näitus - ainulaadne meeleline kogemus. - Sirp, 25. aprill. http://www. sirp.ee/s1-artiklid/c6-kunst/naeitus-ainulaadne-meeleline-kogemus/ (viimati külastatud 15.08.2018). 
Mägi, Marilyn. 2016. ERM: segadusseajav sisu kindlas kuues. - Universitas Tartuensis, 10. http://www.ajakiri.ut.ee/artikkel/2128 (viimati külastatud 15.08.2018).

Männik, Triin; Kristian Kirsfeldt, Jan Graps. 2017. Soome-ugri näitus. - Maja 1-2, 92-95.

Petolai, Berit. 2016. Kajad sinus eneses. ERMi soome-ugri püsinäitusel. - Eesti Rahva Muuseumi ajaveeb. http://blog.erm.ee/?p=8842 (viimati külastatud 15.08.2018).

Porto, Nuno. 2007. From Exhibiting to Installing Ethnography: Experiments at the Museum of Anthropology of the University of Coimbra, Portugal, 1999-2005. - Exhibition Experiments, edited by Sharon Macdonald and Paul Basu. Malden, MA; Oxford, Carlton: Blackwell Publishing, 175-196.

Rattus, Kristel. 2014. Paljuhäälne Eesti: kultuuriloo püsinäituse „Eestimaa kahekõned“ koostamisest Eesti Rahva Muuseumis. - Õpetatud Eesti Seltsi aastaraamat 2013. Tartu, 101-120.

Rattus, Kristel. 2016. Dialoogilisus Eesti Rahva Muuseumi püsinäitusel „Kohtumised“. - Eesti Rahva Muuseumi aastaraamat 59. Tartu: Eesti Rahva Muuseum, 143-161.

Runnel, Pille. 2015. Tehes näitust „\#Niisamalinnas“: kuidas uurida ja mõista laste ja noorte linnaruumikogemusi. - Eesti Rahva Muuseumi aastaraamat 58. Tartu: Eesti Rahva Muuseum, 108-133.

Runnel, Pille; Taavi Tatsi; Pille Pruulmann-Vengerfeldt. 2010. Who Authors the Nation? The Debate Surrounding the Building of the New Estonian National Museum. - National Museums: New Studies from around the World, edited by Simon J. Knell, Peter Aronsson, Arne Bugge Amundsen, Amy Jane Barnes, Stuart Burch and Jen Carter. London; New York, NY: Routledge, 325-338.

Ränk, Gustav. 1929. Hõimurahwaste osakond E.R. Muuseumis. - Postimees, 8 jaanuar: 7.

Salve, Kristi. 2016. Keelepuu varjus. - Eesti Rahva Muuseumi ajaveeb. http://blog.erm. ee/?p=8691 (viimati külastatud 15.08.2018).

Sandahl 2007 = Сэндал, Етта. 2007. Включенный Другой - оксюморон современных этнографических коллекций? Музеи как институции колониализма. Антропологический форум № 6, 87-97.

Seljamaa, Elo-Hanna. 2017. Peegelduv heli. - Sirp, 27. jaanuar. http://www.sirp.ee/s1-artiklid/c6-kunst/peegelduv-heli/; lühendatud kujul - Soome-ugri sõlmed 2016, 55-58.

Sepp, Eva Liisa. 2017. Kuidas Eesti Joonisfilm palus meestel teed juhatada. - Sirp, 25. mai. http://sirp.ee/s1-artiklid/film/kuidas-eesti-joonisfilm-palus-meestel-teed-juhatada/ (viimati külastatud 15.08.2018).

Silla, Priit. 2017. Kes poleks kuulnud? Aga näinud? - Sakala, 22. veebruar. http://sakala. postimees.ee/4022703/kes-poleks-kuulnud-aga-nainud?utm_source (viimati külastatud 15.08.2018).

Zassetskaja 2013 = Засецкая, Марина Львовна. 2013. Временная выставка «И. А. Гальнбек - исследователь эстонской этнографии». - Музей. Традиции. Этничность 1: 106-118.

Zõbin, Janno. 2017. Läbinisti šovinistlik soome-ugri ilm. - Sirp, 7. juuli. http://www.sirp.ee/ s1-artiklid/c9-sotsiaalia/vastulause-labinisti-sovinistlik-soome-ugri-ilm/ (viimati külastatud 15.08.2018).

Tallgren, Aarne Mikael. 1921. Missugune Eesti rahvuslik muuseum peaks olema. - Päevaleht, 25. oktoober; Postimees, 27. oktoober.

Tallgren, Aarne Mikael. 1923. Eesti muuseum ja soome-ugri teaduse alad. - Odamees nr 2, 41-43.

Tatsi, Taavi. 2011. Identity Struggles of Museum Professionals: Autonomous Expertise and Audience Participation in Exhibition Production. - Journal of Ethnology and Folkloristics 5 (2), 65-80.

Thoburn, Nicholas. 2014. Useless Objects: Commodities, Collections and Fetishes in the Politics of Objects. - Penny Harvey, Eleanor Conlin Casella, Gillian Evans, Hannah Knox, Ch- 
ristine McLean, Elizabeth B. Silva, Nicholas Thoburn and Kath Woodward (toim). Objects and Materials: A Routledge Companion. London, New York: Routledge, 208-217.

Tšernenko 2006 = Черненко В. В. 2006. Современные информационные технологии в музее: экспозиционно-выставочный аспект. - Э. И. Черняк (отв. ред.). Музей и современные технологии: Материалы Всероссийских научных конференций. Томск, 20 23 мая 2003 г., 20-24 сентября 2004 г., 19-22 ноября 2005 г. Томск: Изд-во Том. ун-та, $117-127$.

Tšistov 2007 = Чистов, Юрий Кириллович. 2007. Дия того чтобы ответить... Антропологический форум 6: 108-114.

Tulev, Taavi 2017. Kuidas valmis soome-ugri näituse helikujundus. - Maja 1-2: 96-97.

Watson, Sheila. 2007. Museums and their Communities. - Sheila Watson (toim). Museums and their Communities. London and New York: Routledge, 1-23.

Viatte 2007 = Вьят, Жермен. 2007. Этнографические собрания в современном музее. Антропологический форум № 6, 25-31.

Õunapuu, Piret. 2006. Museoloogia ja ajalugu. ICOFOMi aastakonverents Argentiinas. Muиseum 2 (20), 33.

Svetlana Karm on ERMi teadur ja soome-ugri püsinäituse „Uurali kaja“ juhtkuraator. Peamised uurimishuvid on Eesti soome-ugri etnoloogia ajalugu ning etniliste kultuuride esitlemise praktikad muuseumiruumis.

Art Leete on Tartu Ülikooli etnoloogia professor, ERMi püsinäituse „Uurali kaja“ kontseptsiooni autor ja kuraator. Peamised uurimisteemad on seotud põhjapoolsete soome-ugri rahvaste uurimisloo ja nende seas toimuvate sotsiaalsete ja religioossete muutustega. Avaldanud neli monograafiat põhjarahvaste kuvandi, põhjapõdrakasvatuse ja nõukogudevastaste ülestõusude teemal. 


\section{Summary: The Echo of the Urals exhibition at the Estonian National Museum}

\section{Svetlana Karm, Art Leete}

Our objective was to analyse the process of preparing the Echo of the Urals permanent exhibition we produced for the Estonian National Museum. We focused on the historical background of the exhibition and the methodological and ideological positions that the exhibition committee relied on. In this article, we dealt with how the concept for the exhibition developed and the principles for the technical solutions used at the exhibition. We also tried to analyse the retrospective views taken by the exhibition's content and design committees regarding their work.

Many previous Finno-Ugric permanent exhibitions at the Estonian National Museum had focused on presenting folk art, and this aspiration was reflected even in the titles of the exhibitions. Moreover, the Finno-Ugric scholars at the National Museum also tried to use the exhibitions to gain an overview of the existing materials at the museum concerning a specific ethnic group. Such exhibitions also focused on the Finno-Ugric people and so as representative a set of artefacts as possible was placed on display, systematised in the spirit of scientific objectivity. From the second half of the 1990s on, the museum's researchers started producing exhibitions on more experimental themes as well, testing the suitability of various ideas for an ethnographic exhibit. Some ideas are exciting on paper while artefacts can fail to express more abstract qualities. Our permanent exhibition was based on the historical legacy, and we tried to find a simple, relevant starting idea for the exhibition that made full use of the museum's collections. After discussions, we chose Echo of the Urals as the title of the exhibition. In doing so, we tried to refer in a lyrical vein to the idea of an original home for the Finno-Ugrians and allow different peoples to be introduced in a single framework. The idea of linguistic kinship may be easy to understand for scholars and many Finno-Ugrians, but we also thought about visitors who did not know anything about the topic. We devoted the main part of the exhibit to the ethnographic representation of gender roles, trying to get viewers to think about everyday gender roles and cultural differences. We hoped that presenting the cultural roles of males and females would be a simple starting idea that would also be of interest to many. The exhibition design had to be stateof-the-art, a finely tuned machine, at the same time creating emotionally gripping, seemingly semi-natural ethnographic attractions.

As a result of our research, we found that although we tried to create an emotionally captivating and conceptually balanced exhibition, we were criticised in the critical reception for allegedly haphazard choices (the gender theme was criticised) and having a romantic aim to find beauty (to the detriment of reflecting the situation faced by indigenous cultures today). Our analysis of the making of our ethnographic exhibition with ambitious and seemingly conflicting or even simulta- 
neously unattainable goals is limited by the lack of a bystander's perspective and the lack of temporal distance between the completion of the exhibition and the our meta-research. Our main conclusion regarding the process of creating the exhibition consists of thorough conceptualisation intertwined with intuitive aesthetic and intellectual prediction. 


\section{Резюме: Эхо Урала в Эстонском национальном музее}

\section{Светлана Карм, Арт Леэте}

Цель нашего исследования - проанализировать процесс подготовки постоянной финно-угорской экспозиции Эстонского национального музея «Эхо Урала». В статье сосредоточиваемся на историческом контексте выставки, а также на методологических и идеологических подходах, на которые опиралась выставочная команда. Анализируем процесс разработки научной концепции и технических решений, используемых на выставке. Пытаемся, несмотря на небольшой период, прошедший со времени подготовки выставки, представить рефлексию восприятия кураторами и дизайнерами своей работы.

Преобладающее большинство ранних финно-угорских экспозиций ЭНМ сосредоточивалось на презентации народного искусства, это стремление отражадось и в названиях раздичных выставок. С другой стороны, сотрудники музея пытались создавать образы конкретных народов с помощью хранящихся в музее материалов. Такие выставки посвящались определенному финноугорскому народу, и на них обычно выставдялась по возможности самая представительная коллекция предметов, систематизированных в духе научной объективности. Со второй подовины 1990-х годов музеи начади готовить выставки и по экспериментальным темам, проверяя таким образом пригодность раздичных идей для этнографического отображения. Некоторые идеи могут быть интересными на бумаге, однако не все абстракции можно выразить с помощью предметов. В подготовке постоянной экспозиции мы опирались на этот исторический багаж и попытались найти простую и актуадьную ведущую идею, которая бы позводила наиболее полно использовать музейные коллекции в репрезентации финно-угорских культур. В ходе обсуждений остановидись на названии «Эхо Урала», попытавшись в поэтическом кдюче указать на идею финно-угорской прародины и показать культуру разных народов в рамках единой темы. Для ученых и многих финноугров идея языкового родства вполне понятна и объяснима, но при подготовке выставки мы думали и о тех посетителях, кто ранее не был знаком с этой темой. Дия ученых и многих финно-угров идея языкового родства вполне понятна и объяснима, но при подготовке выставки мы думали и о не знакомых с этой темой посетителях. Тематику выставки решили связать с этнографической репрезентацией мужских и женских ролей, пытаясь побудить музейного посетителя к размышлениям как о наших повседневных гендерных ролях, так и о культурных раздичиях. Мы посчитали, что презентация культурных ролей женщин и мужчин - простая идея, представляющая интерес для многих людей. Дизайн выставки должен был отвечать последнему слову техники, создавая, насколько это возможно, эмоционально привлекательную илдюзию этнографической действительности.

В ходе исследования выявилось, что, хотя стремились создать эмоционально привлекательную и концептуально сбалансированную экспозицию, в отзывах 
на выставку прозвучали критические замечания относительно случайных выборов (ведущих к пропаганде гендерного неравенства) и стремления к романтизации финно-угорских культур (вместо показа современного положения коренных народов). Ввиду отсутствия взгдяда извне и малой временной дистанции между подготовкой выставки и написанием данной статьи, (авто)рефлексивный анадиз процесса создания этнографической экспозиции с широкими и, казалось бы, одновременно противоречивыми или нереальными целями является ограниченным. Главный вывод исследования: выставочный процесс - это сочетание глубокой концептуадизации с интуитивным эстетико-интеллектуадьным предвидением. 